\title{
The Effects of Governance on Classification Shifting and Compensation Shielding
}

\author{
Jeong Hwan Joo* \\ Faculty of Business and Economics \\ The University of Hong Kong \\ Tel.: +8523917 1629 \\ Email: jeongjoo@hku.hk \\ Sandra Chamberlain \\ Sauder School of Business \\ University of British Columbia \\ Tel.: +1 6048228531 \\ Email: Sandra.chamberlain@sauder.ubc.ca
}

June 19, 2016

* Corresponding Author.

The paper has benefitted from insightful comments and suggestions of two anonymous referees and Partha Mohanram (editor). We thank Qiang Cheng, Xia Chen, Kin Lo, David Maber, Mark Evans, Chul W. Park, Steve Matsunaga, Joy Begley, Ralph Winter and participants at the 2010 CAAA Annual Meeting and the 2012 AAA Annual Meeting for discussing this paper with us and helping us to move it forward. Finally, we thank workshop participants and colleagues at the University of Hong Kong and University of British Columbia. 


\begin{abstract}
:
Prior research (e.g., Dechow, Huson, and Sloan 1994) documents that, on average, compensation practices appear to shield CEO pay from income-decreasing special items. In some circumstances, compensation shielding can be efficient. For example, it may encourage CEOs with earnings-sensitive pay to take an action that reduces current earnings but nevertheless enhances value. Compensation shielding can be inefficient in other circumstances, such as when a board of directors is captured by an overly-powerful CEO or the magnitude of negative special items has been overstated (e.g., by shifting core expenses into special items.) This paper explores whether strong governance can explain cross-sectional variation compensation shielding, and whether stronger governance and auditing are associated with less shifting of expenses. We find that strong corporate governance mechanisms, as captured by board (and committee) independence, the Sarbanes-Oxley (2002) Act (SOX) and its related governance reforms, and switches to Big-4 auditors, are all associated with less compensation shielding. While our evidence suggests that strong overall governance is associated with a reduction in manipulation of core earnings through classification shifting in the cross-section, we find inconclusive evidence to suggest that board independence or SOX influence classification shifting.
\end{abstract}

Keywords: CEO Compensation, Compensation Shielding, Special Items, Classification Shifting, Corporate Governance, Board Independence

JEL Classifications: M41, G38, J33

Data Availability: All data used in the study are available from public sources. 


\section{Introduction}

Prior research finds that CEO compensation is shielded from negative (incomedecreasing) special charges (Dechow, Huson, and Sloan 1994; Gaver and Gaver 1998; Adut, Cready, and Lopez 2003). That is, the level of annual compensation paid to the average CEO places a higher weight on earnings before negative special items than it does on negative special items. Defined by Accounting Principles Board (APB) Opinion No. 30, special items are unusual or infrequent expenses that are involved in transactions or activities, such as restructuring, gains on sale of assets, or litigation costs. An agency-theoretic view can characterize compensation shielding as efficient. For example, compensation shielding can encourage risk-averse CEOs to take long-term value-enhancing actions (e.g., restructuring) that decrease short-term profits (e.g., Dechow et al. 1994). Alternatively, self-interest could lead CEOs to take advantage of weak paysensitivity to these infrequent charges by shifting some normal expenses into the special items category. This subtle form of earnings management, known as classification shifting (e.g., McVay 2006), leaves bottom-line net income unchanged. We are interested in the interplay between classification shifting, pay shielding, and corporate governance.

This paper asks two questions. First, does stronger governance measured at board and board committee level, and by external audit quality, imply reduced earnings management in the form of shifting core expenses into negative special items? Second, when classification shifting is likely to have occurred, does stronger governance imply less shielding of pay from negative special items? We draw data from 1995-2012, a time period characterized both by tightening of rules on the composition of boards of directors (e.g., the enactment of the Sarbanes-Oxley (2002) Act (SOX) ) and increased public scrutiny of executive pay practices. In a similar manner to Chhaochharia and Grinstein (2009), we exploit the requirements for strengthened board independence imposed around SOX to capture relatively exogenous changes in board independence. This allows us to use difference-in-differences tests to incorporate good controls for 
endogeneity and omitted variables. However, this research design choice leads us to employ a relatively small sample; therefore, for a larger sample, this paper's questions are also analyzed in cross-section using firm-year measures of overall governance strength and audit quality.

Since classification shifting is used to manipulate core earnings, we start by estimating excessive core earnings using models of "normal" core earnings from McVay (2006), and Fan, Barua, Cready, and Thomas (2010). We test whether stronger governance reduces classification shifting by regressing estimated abnormal core earnings from these models on the absolute magnitude of negative special items. As in McVay (2006), a positive coefficient indicates classification shifting on average; we test if the coefficient is less positive when oversight is stronger.

The evidence is mixed. The difference-in-differences analysis yields almost no support for the hypothesis that classification shifting of core expenses is sensitive to board independence or SOX. However, using cross-sectional tests, classification shifting varies inversely with a broad index of governance strength that captures characteristics beyond board independence. Also, audit quality as captured by switching to or from a Big 4 auditor relates to classification shifting as predicted. These particular cross-sectional results are consistent with our hypothesis.

Our hypothesis that stronger governance is associated with less shielding of misclassified negative special items finds more consistent support. The difference-in-differences results suggest that, post-2002, there is generally less shielding of incentive compensation from negative special items. Also, mandated increases in board independence are incrementally associated with less compensation shielding. Cross-sectional analyses that employ the broad governance index confirm that stronger oversight ties to a larger compensation weight on our measure of misclassified negative special items (i.e., less pay-shielding).

Summing up, the tests suggest that stronger governance is linked to higher sensitivity of CEO pay to misclassified negative special items. However, classification shifting per se does not 
consistently decrease in all measures of stronger governance, across our two research designs. To some readers the classification shifting results may seem to contradict the pay-sensitivity findings. We cite theoretical work suggesting that both outcomes are feasible if pay-performance sensitivity and earnings management are jointly determined

This paper adds to the literature on the interplay between CEO compensation and earnings management. We rely on theoretical work by Goldman and Slezak (2006), Laux and Laux (2009), and Dutta and Fan (2014) to provide intuition for this interplay. These agency models recognize two key tasks of boards: setting pay policies and monitoring accounting choices. An important base assumption in these models is that information asymmetry prevents the principal from detecting earnings management with certainty. ${ }^{1}$ The first two works yield the direct prediction that pay-performance sensitivity is weaker when accounting oversight is less effective (i.e., more pay shielding), our second hypothesis. However, the predicted impact of stronger governance on earnings management is ambiguous. Under these models, an increase in the detection probability of, and penalties for, earnings management have direct negative effects on earnings management incentives (our first hypothesis). Yet the higher pay sensitivity on earnings invites further earnings management. Hence a regulatory change that is intended to curb earnings management can lead to an increased, reduced, or unchanged level. ${ }^{2}$

The cited models capture an abstract version of earnings management while we investigate the effect of governance on a specific form of earnings management, namely, "core" earnings management via classification shifting. We contend that the results of our data-based research can shed light on the net importance of underlying direct and indirect effects of three factors of interest-governance mechanisms, the structure of CEO pay, and classification shifting.

\footnotetext{
${ }^{1}$ In these models, if earnings management can be detected with certainty, it is undone by compensation committees and is irrelevant.

${ }^{2}$ We use directional hypotheses to streamline the presentation, but there is sufficient hypothesis tension to justify two-sided hypotheses. All statistical tests are two tailed.
} 
Prior empirical research focuses on two of these three factors at a time. Papers such as Cheng and Warfield (2005), Bergstresser and Phillipon (2006), and Burns and Kedia (2006) show that CEO pay structures create incentives that lead to earnings management. ${ }^{3}$ These papers capture CEO pay structure based on equity incentives, and use discretionary accruals, accounting restatements or fraud to capture accounting manipulation. A second literature includes Carter, Lynch, and Zechman (2009) and Chhaochharia and Grinstein (2009). These papers show that exogenous governance changes imposed in 2002 have influenced CEO pay packages and payperformance sensitivity. A third stream examines whether earnings management is less prevalent in the presence of stronger governance mechanisms (Klein 2002; Bergstresser and Philippon 2006). Our paper links governance and pay to a different form of earnings management, namely classification shifting. Although there is existing research on classification shifting (McVay 2006; Fan et al. 2010), and compensation shielding (Dechow et al. 1994; Gaver and Gaver 1998; Adut et al. 2003), these are separate streams that do not link governance structures to these practices. ${ }^{4}$

Further, evidence on our research questions helps to complete the picture provided by existing work concerning the effects of SOX regulation and governance on performance measures and CEO pay. Chhaochharia and Grinstein (2009) find that CEO compensation decreased following the 2002 reforms. Their Table 2 (Columns 3 and 4) shows that total compensation was more sensitive to ROA following SOX for all firms. Our results suggest that this finding, in part, reflects increased pay sensitivity to negative special items in the post-SOX period (i.e., there is less shielding), and that this pay practice co-varies with committee independence. With regard to

\footnotetext{
${ }^{3}$ Early research includes Healy (1985), Gaver, Gaver, and Austin (1995), and Holthausen, Larker, and Sloan (1995), among others.

${ }^{4} \mathrm{Haw}, \mathrm{Ho}$, and $\mathrm{Li}$ (2011) touch on the link between governance and classification shifting. They find classification shifting in East Asian countries increases in the presence of weaker legal institutions and opaque disclosure, and for firms with controlling shareholders. In comparison, we use the North American regime with strong legal systems and relatively transparent accounting. Our governance variables are firm and time specific.
} 
earnings management, Cohen, Dey and Lys (2008), and Cheng, Chen and Wang (2015) find a decrease in discretionary accruals following SOX, while Cohen et al. (2008) document an increase in the use of real earnings management tools. ${ }^{5}$ In our case, classification shifting does not reliably decrease post-SOX, though some tests suggest its use weakens as governance improves.

We provide additional context on measuring classification shifting in Section 2. This leads to a discussion of other components of negative special items. We also develop our hypotheses in this part of the paper. Section 3 contains key research design choices while Section 4 reports our main results. Section 5 contains supplementary analysis and Section 6 concludes.

\section{Negative Special Item Components, Pay Shielding and Hypothesis Development}

Overview on Measuring Classification Shifting and Pay Shielding

Classification shifting refers to the improper loading of core expenses into negative special items. This creates excessive core earnings without changing total earnings; that is, increases in core earnings are offset by an equal increase in negative special items. Compensation shielding refers to the empirical regularity that there is weaker pay sensitivity to negative special items than there is to core earnings, defined (roughly) as earnings before negative special items (e.g., Adut et al. 2003). We link compensation shielding to classification shifting, and we therefore require a measure of classification shifting.

Agency theoretic models that allow for earnings management assume that manipulation cannot be detected with certainty by the principal. Given this, researchers should not expect to measure manipulation perfectly. Our proxy for "excessive core earnings" contains measurement error, which is transferred to our proxy for classification-shifted expenses. If this error is correlated with model variables, it affects our ability to draw valid inferences. While we rely on

\footnotetext{
${ }^{5}$ Other studies exploit the 2002 regulatory changes to explore the effects of governance on financial reporting and performance. For example, Donelson, McInnis, and Mergenthaler (2015) report a reduction in accounting fraud following SOX, and Armstrong, Core, and Guay (2014) report a reduction in information asymmetry.
} 
models of classification shifting from the prior literature, we cannot eliminate measurement error.

Following McVay (2006), "excessive core earnings" is measured as the residual term from an industry-year regression of a proxy for core earnings (operating income before depreciation expense and before special items, CE) on economic determinants. If this measure is positive in the same period that negative special items are recorded, we label the excessive core earnings as "classification shifted" expenses (CS). We subtract CS from the total of negative special items (NSI) to identify the portion of negative special items that are "not classification-

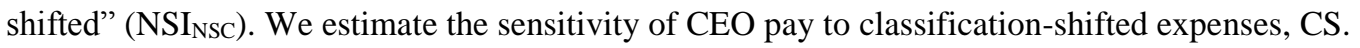
The pay weight on CS tells us whether CEO pay is shielded from the portion of negative special items that is most subject to classification shifting. We discuss below the accounting practices for all components of negative special items to provide insight on CS and $\mathrm{NSI}_{\mathrm{NCS}}$.

\section{Components of Negative Special Items and Classification Shifting}

Negative special items arise when firms' economic circumstances create the need for write-offs or reserves. These infrequent or unusual expenses are reported "above the line" contributing to the Generally Accepted Accounting Principles (GAAP) measure of continuing operations. Yet analysts tend to define core earnings as income before these special charges, and at some firms, compensation policies explicitly use pro-forma earnings (before these items) to measure performance (Appendix 1). Examples of negative special items are restructuring charges, merger-related costs, asset write-downs, litigation reserves, and losses on sales of assets.

Among the types of negative special items, charges related to restructurings or mergers are most prone to classification shifting (McVay 2006, Page 506). Managers can misclassify normal severance charges, and day-to-day legal fees and other administrative expenses, as charges and fees related to the restructuring or merger.

Prior to 2002, Emerging Issues Task Force (EITF) Issue No. 94-3 provided the relevant accounting rules for restructuring charges. EITF 94-3 states that restructuring charges can be 
recognized when a company commits to a restructuring plan and if the costs recognized have no further future benefits. ${ }^{6}$ McVay (2006), and Bens and Johnston (2009) confirm that discretion under EITF Issue No. 94-3 provided opportunities for the manipulation of these charges.

The discretion under EITF Issue No. 94-3 to shift expenses forward in time was reduced in 2002 by the passing of Financial Accounting Standard (FAS) 146. This standard specifies that restructuring-related expenses be recognized when costs are incurred. Lee (2014) provides confirmatory evidence that FAS 146 has been effective. While FAS 146 surely limits expense shifting across time, the increased scrutiny of expense recognition might also impact vertical expense shifting (i.e., classification shifting). Therefore, FAS 146 provides a reason, beyond SOX, to view 2002 as an intervention year for classification shifting.

Based on accounting practices for items that are eligible for the special items category, the "non-classification shifted" component of negative special items ( $\mathrm{NSI}_{\mathrm{NCS}}$ ) consists of three parts: i) expenses that properly belong in special items due to an event such as a restructuring or a merger; ii) other special items that are not amenable to vertical shifting, such as losses on sales of assets and write-downs; and iii) the negative of any measurement error in CS. There is an extensive literature on write-downs, including Francis, Hanna, and Vincent (1996), Riedl (2004), and Beatty and Weber (2006). These papers suggest the timing and magnitude of write-downs are discretionary. Since $\mathrm{NSI}_{\mathrm{NSC}}$ contains both the negative of measurement error in CS, and, other discretionary charges such as write-downs, we do not make a prediction for its pay weight.

Development of hypotheses

We test two main hypotheses on the effects of stronger governance on compensation shielding and classification shifting. Bear in mind we measure stronger governance based on

${ }^{6}$ EITF Issue No. 94-3 gave latitude for firms to shift both current and future expenses to negative special items, creating a big bath. However, this standard requires footnote disclosures that discipline big baths. Specifically firms were required to list the types of restructuring costs by use, and to provide ongoing reconciliations of the cash flows associated with the recognized obligation. 
whether the compensation and audit committees or the board as a whole meet post-SOX independence standards, and based on whether a firm-year falls into the post 2002 period. We also use Big 4 audit indicators and a firm-year index of overall governance strength.

HYPOTHESIS 1. Firm-years with weaker governance practices exhibit greater classification-shifting of expenses from core earnings to negative special items. HYPOTHESIS 2. Compensation practices at firm-years with weaker governance practices are more likely to shield pay for classification-shifted expenses.

These hypotheses follow from the simple reasoning that a CEO can benefit from classification-shifted expenses because this overstates the board's perception of core earnings, and core earnings has relatively high pay-performance sensitivity (e.g., Appendix 1$){ }^{7}$ Since classification shifting is counter to sound accounting practice, and our measures of better governance (e.g., board and committee independence) intend to capture the effort and precision of the audit function, we expect that better governance will be associated with reduced classification shifting. ${ }^{8}$ Similarly, since stronger governance should avoid inefficient pay practices, we conjecture boards will place a greater discount on core earnings when recurring expenses are likely to have been shifted into special items. These two hypotheses depend on there being crosssectional variation in firms' costs or abilities to detect and prevent earnings management, and in firms' willingness to scrutinize performance measures that are used in pay practices. We are proposing that our various governance constructs capture this cross-sectional variation.

However, agency theoretic models of the three factors we examine-governance, earnings management and CEO pay—suggest our directional hypotheses do not take into account simultaneity between incentive pay and earnings manipulation. Such models (e.g., Goldman and

\footnotetext{
${ }^{7}$ We assume that the board does not measure core earnings without noise.

${ }^{8}$ This is the reasoning used in Klein (2002) for her expectation that more independent audit committees would be associated with lower discretionary accruals (page 378, last sentence).
} 
Slezak 2006; Laux and Laux 2009) designate a risk averse CEO as the agent and a risk neutral shareholder or the board of directors as the principal. CEO actions are not observable, but both principal and agent hold common beliefs about the effects of actions on the distribution of outcomes, and each party knows the other's utility function. Specifically, the CEO can undertake productive actions to maximize firm value and non-productive actions that add bias to earnings. Conflicts in the objectives of the CEO and the principal arise from their respective difference in utility for these productive and non-productive actions. The principal anticipates that earnings are managed and adjusts pay and pay-performance sensitivity with this moral hazard in mind (Laux and Laux page 877, Goldman and Slezak page 605). ${ }^{9}$ The expectation of earnings management dampens pay-performance sensitivity to overall earnings.

The better the audit technology, meaning the better the detection of and the greater are penalties for earnings management, the less incentive the manager has to manipulate the performance measure (H1) and the larger is pay sensitivity to earnings components (H2). Better audit technologies make overall perceived core earnings more revealing of productive effort. However, the increase in pay-performance sensitivity further tempts the manager to manipulate earnings. Because of this spillover, the net impact on earnings management is ambiguous. ${ }^{10}$

Both Goldman and Slezak (2006), and Laux and Laux (2009) maintain an assumption that CEOs can profit from earnings management (e.g., through liquidating stock grants) before the board is able to observe the true economic state of the firm. The equilibrium outcomes change if this assumption is not true, and this introduces tension into our second hypothesis (H2). For

\footnotetext{
${ }^{9}$ This does not mean that the earnings management is "detected." It simply means that all parties understand that earning management is occurring if this is a rational choice for the CEO.

10 "Earnings management" in the theoretical papers is abstract (see also footnote 11.) In our specific context (classification shifting), we envision stronger boards increase the pay weight on perceived core earnings and perceived core earnings should include the board's estimate of recurring expenses that appear in special items. This leads to an uncertain net effect on classification shifting because an increase in core earnings sensitivity tempts more forms of classification shifting (which we capture empirically through the total CS).
} 
example, Dutta and Fan (2014) assume that earnings management is achieved through reversing accruals. A period $t$ manipulation creates a short-term bias in investor's perceptions of firm value. This bias reverses in $t+1$ when the accrual reverses. Dutta and Fan also assume firms can precommit to future pay contracts when the CEO is hired. Given the assumptions in Dutta and Fan, average pay-performance sensitivity can be higher (lower) in the face of better auditing technology if the manager's productivity increases (decreases) over time.

The abovementioned equilibrium models show how feedback to and from payperformance sensitivity leads to ambiguity in the relation between governance and earnings management. Yet, these models are an over-simplification. They do not address the specific form of earnings management we investigate or the governance measures that we capture. ${ }^{11}$ In addition, the directional impact of stronger governance on classification shifting and pay-performance sensitivity will be influenced by factors that lie outside the models, including the costs of other earnings management tools or the firm-specific contract terms. ${ }^{12}$ Relatively minor changes in the theoretical assumptions can lead to alternative predicted effects of governance on payperformance sensitivity or classification shifting. Therefore, we test our naïve directional hypotheses using two-tailed tests.

\section{Research design}

\footnotetext{
${ }^{11}$ For example, earnings management in Goldman and Slezak (2006) occurs when an auditor is convinced by management to issue a biased report of share value in period 2, and "governance" is captured by fines and penalties that attach to the discovery of earnings management with some probability. To equate this abstraction to our setting, classification shifting would cause shareholders to misestimate value based on latent core earnings, and our governance measures (e.g., independent boards) correspond to penalties for and detection of earnings management. ${ }^{12}$ Some prior studies report evidence that accrual manipulation decreases, while real activity manipulation increases, when stricter accounting standards or governance rules are adopted (Ewert and Wagenhofer 2005; Cohen et al. 2008). If classification shifting is a relatively low cost mechanism to manipulate performance measures, increased regulation that reduces firms' willingness to manipulate accruals across time could lead to an increase in classification shifting. Appendix A provides some insight on how different firms conceptualize core earnings. Of course not all firms define their measure explicitly.
} 


\section{Estimating misclassified income-decreasing special items}

To estimate unexpected core earnings (UE_CE), we use the error term from industry-year regressions of core earnings (CE) on lagged core earnings and control variables. The regressions are based on McVay (2006) (Equation 1, subscripts “M”) and Fan et al. (2010) (Equation 2, subscripts "F") as follows ${ }^{13}$ :

$$
\begin{aligned}
& \mathrm{CE}_{t}=\alpha_{\mathrm{M}, 0}+\alpha_{\mathrm{M}, 1} \mathrm{CE}_{t-1}+\alpha_{\mathrm{M}, 2} \mathrm{ATO}_{t}+\alpha_{\mathrm{M}, 3} \text { ACCRUALS }_{t-1}+\alpha_{\mathrm{M}, 4} \text { ACCRUALS }_{t}+\alpha_{\mathrm{M}, 5} \Delta \text { SALES }_{t} \\
& +\alpha_{\mathrm{M}, 6} \mathrm{NEG} \Delta \mathrm{SALES}_{t}+\varepsilon_{t}
\end{aligned}
$$

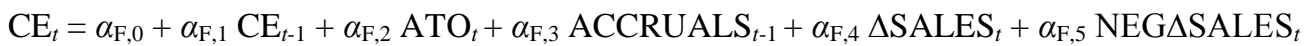

$$
\begin{aligned}
& +\alpha_{\mathrm{F}, 6} \mathrm{RET}_{t}+\alpha_{\mathrm{F}, 7} \mathrm{RET}_{t-1}+\varepsilon_{t}
\end{aligned}
$$

Appendix 2 defines these variables in detail. Following $\mathrm{McVay}_{\mathrm{C}} \mathrm{CE}_{t}$ is captured by operating income before special items and before depreciation expense (i.e., revenues minus cost of goods sold and selling and administrative expenses); this is deflated by sales for year $t$.

McVay (2006) provides a justification for the independent variables that capture the economic determinants of core earnings. Lagged core earnings $\left(\mathrm{CE}_{t-1}\right)$ controls for the serial correlation of core earnings, while the asset turnover ratio for year $t\left(\mathrm{ATO}_{t}\right)$ has been shown to be inversely related to operating income deflated by sales (Nissim and Penman 2001). Total accruals deflated by sales for year $t\left(\right.$ ACCRUALS $\left._{t}\right)$ control for normal core earning that are generated by firm performance (DeAngelo, DeAngelo, and Skinner 1994), while lagged total accruals (ACCRUALS ${ }_{t-1}$ ) are included based on empirical evidence on the ability of accruals to predict future earnings (Sloan 1996). Sales growth for year $t\left(\Delta \mathrm{SALES}_{t}\right)$ influences operating income deflated by sales by decreasing fixed costs per unit. Finally, negative sales growth for year $t$ $\left(\mathrm{NEG} \triangle \mathrm{SALES}_{t}\right)$ captures potential asymmetric effects of sales growth when sales decline.

McVay (2006) acknowledges that her evidence of classification shifting is sensitive to the inclusion of current period accruals as a performance control. Fan et al. (2010) emphasize that

\footnotetext{
${ }^{13}$ Industries are defined across 48 sectors as suggested in Fama and French (1997).
} 
including current period accruals can lead to a violation of OLS assumptions, and a mechanically induced positive relation between unexpected core earnings and negative special items. They replace current-period accruals with current and lagged stock returns $\left(\operatorname{RET}_{t}\right.$ and $\left.\mathrm{RET}_{t-1}\right)$. Given the likely noise and unknown bias in our proxy for unexpected core earnings, we use both the McVay (2006) and Fan et al. (2010) models.

In tests of pay-performance sensitivity, $\mathrm{H} 2$, the proxy for misclassified negative special items, $\mathrm{CS}_{t}$ is either positive, or zero. It is equal to unexpected core earnings $\left(\mathrm{UE}_{-} \mathrm{CE}_{t}\right)$, provided this number is positive (i.e.,UE_CE $>$ $>0$ ) and provided negative special items scaled by revenues are non-zero (i.e., $\mathrm{NSI}_{t}>0$ ). ${ }^{14}$ This definition intends to maximize the signal to noise in CS for the pay regressions. Our reasoning is that since shifting expenses implies an overstatement of core earnings, positive excessive core earnings are likely a better indicator of classification shifting than negative excessive core earnings. Implicitly, our measurement scheme designates the combination of a negative UE_CE and a non-zero NSI as an instance where no classification shifting has occurred. Since UE_CE is unobservable and is measured with error, this procedure can cause us to miss valid classification shifting. Also we fail to measure classification shifting if this has actually occurred when special items are positive rather than negative.

Consistent with prior classification shifting studies, to validate the classification shifting metric and test $\mathrm{H} 1$, we regress unexpected core earnings $\left(\mathrm{UE}_{-} \mathrm{CE}_{t}\right)$, which can be positive or negative, on negative special items $\left(\mathrm{NSI}_{t}\right)$, i.e.,

$$
\mathrm{UE} \_\mathrm{CE}_{t}=\beta_{1} \mathrm{NSI}_{t}+\mathrm{FE}+\varepsilon_{t}
$$

Here FE is year- and firm-fixed effects (hence the lack of an intercept.) As in McVay (2006) and Fan et al. (2010), we interpret a positive coefficient on NSI to suggest that classification shifting is

\footnotetext{
${ }^{14}$ Compustat combines special items that are shown on the income statement or disclosed in footnotes. NSI equals special items multiplied by -1 deflated by revenue if special items are negative and 0 otherwise. Special items are negative if negative elements such as restructuring charges dominate positive elements such as gains on sales of assets.
} 
likely, (i.e., $\beta_{1}>0$ ). In contrast, $\beta_{1}=0$ suggests that unexpected core earnings are unrelated to negative special items and that expenses have not been classification-shifted. ${ }^{15}$

Note that we make no attempt to reduce measurement error in our dependent variable for equation (3). UE_CE is a noisier measure of classification shifting than CS. If we were to use CS as the dependent variable in Equation 3 to test H1, given our definition of CS, there would be a mechanical positive relation between CS and NSI.

Shielding CEO compensation from misclassified negative special items - Base case

We detect whether pay is shielded from special items by measuring the pay-performance sensitivity of total incentive pay (INCPAY ${ }_{t}$ ) to earnings before negative special items (EBNSI), to the classification-shifted component of negative special items (CS), and to the remaining component of negative special items ( $\left.\mathrm{NSI}_{\mathrm{NCS}}\right)$. Equation 4 defines this model.

$$
\mathrm{INCPAY}_{t}=\gamma_{1} \mathrm{NSI}_{\mathrm{NCS}, t}+\gamma_{2} \mathrm{CS}_{t}+\gamma_{3} \mathrm{EBNSI}_{t}+\mathrm{CONTROLS}_{t}+\mathrm{FE}+\varepsilon_{t}
$$

Specifically, total incentive pay, $\mathrm{INCPAY}_{t}$, is the logarithm of one plus CEO incentive pay, which is measured as the sum of cash incentives (i.e., annual bonus and non-equity incentive plan grants) and equity grants (i.e., restricted stock grants and option grants). The coefficient, $\gamma_{3}$ on earnings before negative special items (EBNSI) can be viewed as the base sensitivity of pay to core earnings. The coefficient on CS, $\gamma_{2}$, implies shielding if it is zero, or if it is negative, partial shielding would apply if this coefficient is smaller in absolute value than the coefficient on EBNSI. If the parameter is greater than zero, then classification-shifted expenses are treated in pay as if they represent positive net present value investing. Our measure of the remaining component of negative special items ( $\mathrm{NSI}_{\mathrm{NCS}}$ ) can be either positive (meaning it contains losses) or negative. A negative coefficient on $\mathrm{NSI}_{\mathrm{NCS}}$, if smaller in absolute value than the coefficient on earnings, implies pay shielding. Based on the heterogeneous nature of $\mathrm{NSI}_{\mathrm{NCS}}$, it is difficult to

\footnotetext{
${ }^{15}$ Assuming Equations 1 and 2 are well specified, a negative $\beta_{1}$ suggests that poor performance is reflected in both unexpected core earnings and negative special items.
} 
predict the magnitude of its compensation weighting.

The control variables are inspired by Core, Holthausen, and Larcker (1998). In addition to including EBNSI, there are market-based performance measures: stock returns and negative stock returns $\left(\mathrm{RET}_{t}\right.$ and $\left.\mathrm{D}_{\mathrm{NEG}, t} \mathrm{RET}_{t}\right){ }_{{ }^{16}}$ Risk-averse executives demand higher remuneration when operating performance is riskier; we control for this using the standard deviations of EBNSI and RET estimated using the past five years $\left(\mathrm{STDEBNSI}_{t}\right.$ and $\left.\mathrm{STDRET}_{t}\right)$. Investment opportunities $\left(\mathrm{INVOPP}_{t}\right)$ are captured using the past five-year average market-to-book ratio of total assets. The logarithm of total assets at the start of year $t\left(\right.$ LOGASSETS $\left._{t-1}\right)$ captures the response of pay to managerial effort or ability that is assumed to be in proportion to firm size.

Effects of regulatory changes in corporate governance on compensation shielding

To test our two hypotheses using the difference-in-differences approach, we employ board or committee independence as proxies for the strength of corporate governance. We also identify the year 2002 as giving rise to an exogenous shift in board independence, particularly for the subset of firms that had weaker governance. Similar to Chhaochharia and Grinstein (2009) and Duchin et al. (2010), we compare classification shifting and compensation shielding between firms that were, or were not, already in compliance with the board independence requirements prior to 2002. Firms that were non-compliant prior to 2002 were forced to comply with new standards from 2002, and this is the "treatment" effect of the new regulations for some firms.

The tests use three different sets of treatment and control firms for three different aspects of the 2002 independence requirements. Specifically, we define treatment and control firms for the two separate requirements that audit and compensation committees be $100 \%$ independent, and for a third requirement that the overall board comprise at least 50\% independent directors.

The use of 2002 as the intervention year for the imposition of independence rules follows

\footnotetext{
${ }^{16}$ Allowing different pay sensitivity to negative returns is based on Leone, $\mathrm{Wu}$, and Zimmerman (2006).
} 
prior research. The actual timing of the regulation was not precise. On December 14, 1999, the SEC approved suggested amendments to the listing standards of NYSE and NASDAQ ${ }^{17}$ requiring all audit committee members to be independent directors. However, as of 1999, the term “independence" was not well defined. This rule was amended in 2002 following the Enron and WorldCom scandals. In addition to reiterating the $100 \%$ independent audit committee membership rule, the NYSE and NASDAQ offered a more formal, stricter definition of the term “independent." In 2002, the NYSE also proposed that the majority of the overall board and all compensation committee members be independent. These listing rules were approved by the SEC in 2003, and took effect with firms’ first annual meeting after January 15, 2004.

To identify treatment and control firms, we examine compliance with the various postSOX independence rules as of the start of 2000, at which time firms would not have known of the upcoming mandated changes. We also check for compliance at fiscal year-end 2000 and 2001 using the IRRC/RiskMetrics indicator, I. ${ }^{18}$ A treatment (control) firm must be identified as noncompliant (compliant) every year (i.e., in 1999, 2000, and 2001) to be retained in our sample. We define a dummy variable, NCOMPLY, equal to one for each firm-year, pre- (and post-) 2002 for the treatment firms, and zero for the control firms. To ensure that control firms were in compliance with post-SOX standards prior to entering our sample, we drop 1999 observations. A second dummy variable, POST, is one in 2003-2006 and zero for 2000 and 2001. By interacting POST and NCOMPLY variables with CS and $\mathrm{NSI}_{\mathrm{NCS}}$, including main effects and a three-way interaction, we compare firms in- and out of-compliance, before and after 2002. We

\footnotetext{
17 The amended listing requirements evolved from the Blue Ribbon Committee on Audit Effectiveness, formed at the request of the SEC chairman, Arthur Levitt in September 1998. Klein (2003), and Chhaochharia and Grinstein (2009) provide helpful background, repeated here for the reader's convenience.

${ }^{18}$ IRRC/RiskMetrics codes a director as independent if she or he is unaffiliated with the company. For example, directors who are former employees of the firm, or of a major customer or service provider of the firm, are not independent. Chhaochharia and Grinstein (2009) point out that the IRRC/RiskMetrics independence definitions are stricter than the true 2002 exchange requirements.
} 
remove the first-year regulatory transition effects by dropping 2002 observations. The sample ends in 2006 to avoid confounding effects of the financial crisis.

We adapt the base-case regressions (Equations 3 and 4), including fixed effects:

$\mathrm{UE}_{-} \mathrm{CE}_{t}=\beta_{1} \mathrm{NSI}_{t}+\beta_{2} \mathrm{NSI}_{t} \times \mathrm{NCOMPLY}_{t}+\beta_{3} \mathrm{NSI}_{t} \times \mathrm{POST}_{t}+\beta_{4} \mathrm{NCOMPLY}_{t} \times \mathrm{POST}_{t} \times \mathrm{NSI}_{t}$

$+\beta_{5} \mathrm{NCOMPLY}_{t}+\beta_{6} \mathrm{POST}_{t}+\beta_{7} \mathrm{NCOMPLY}_{t} \times \mathrm{POST}_{t}+\mathrm{FE}+\varepsilon_{t}$

$\mathrm{INCPAY}_{t}=\left(\gamma_{1}+\gamma_{3} \mathrm{NCOMPLY}_{t}+\gamma_{5} \mathrm{POST}_{t}+\gamma_{7} \mathrm{NCOMPLY}_{t} \times \mathrm{POST}_{t}\right) \times \mathrm{NSI}_{\mathrm{NCS}, t}$ $+\left(\gamma_{2}+\gamma_{4} \mathrm{NCOMPLY}_{t}+\gamma_{6} \mathrm{POST}_{t}+\gamma_{8} \mathrm{NCOMPLY}_{t} \times \mathrm{POST}_{t}\right) \times \mathrm{CS}_{t}+\gamma_{9} \mathrm{NCOMPLY}_{t}$ $+\gamma_{10} \mathrm{POST}_{t}+\gamma_{11} \mathrm{NCOMPLY}_{t} \times \mathrm{POST}_{t}+\gamma_{12} \mathrm{EBNSI}_{t}+\mathrm{CONTROLS}_{t}+\mathrm{FE}+\varepsilon_{t}$

In Equation 5, $\beta_{3}$, the coefficient on NSI×POST, captures the effect on classification shifting of the governance and accounting changes that occurred after 2002 (e.g., SOX and FAS 146). We expect $\beta_{3}$ to be negative under H1. Similarly, the incremental effect of board and committee independence for non-compliant firms after SOX is captured by $\beta_{4}$ which multiplies NCOMPLY $\times$ POST $\times$ NSI. This coefficient should be negative if more intense scrutiny of accounting (i.e., higher board independence) reduces classification shifting.

In Equation 6, the coefficient on POST $\times \mathrm{CS}, \gamma_{6}$, reveals the effect of SOX regulatory reforms, generally, on the compensation shielding of classification-shifted expenses. Under H2, we conjecture $\gamma_{6}$ is negative. We expect the coefficient on NCOMPLY $\times$ POST $\times$ CS, $\gamma_{8}$, to be negative because it picks up the incremental effect of improvements in board independence on compensation shielding.

Cross-sectional tests of Hypotheses 1 and 2

To complement and extend our analysis to a longer time period, we employ a crosssectional association regression using a time-varying index to capture the strength of corporate governance. We use factor analysis to reduce a set of nine firm characteristics to a continuous corporate governance index $\left(\mathrm{GOV}_{t}\right.$, see Appendix 2). We appeal to Core et al. (1998) and Hartzell and Starks (2003) for the inputs to the factor model. These inputs measure the degree of management entrenchment, the monitoring intensity of the board, and the degree of shareholder- 
manager incentive alignment (captured through ownership). Board-specific variables comprise the following: an indicator for CEO duality, board size, the ratio of independent directors, independent directors over age 69, and busy directors on multiple boards (Core et al. 1998). Ownership structure variables comprise the following: CEO ownership as a percentage of shares outstanding, an indicator for non-CEO insiders with ownership greater than 5\%, the number of outside block holders with ownership over 5\%, and institutional investors' ownership as a percentage of shares outstanding.

We test for the mediating effect of this broad measure of governance on classification shifting and compensation shielding using the following equations.

$\mathrm{UE}_{-} \mathrm{CE}_{t}=\delta_{1} \mathrm{NSI}_{t}+\delta_{2} \mathrm{GOV}_{t}+\delta_{3} \mathrm{NSI}_{t} \times \mathrm{GOV}_{t}+\mathrm{FE}+\varepsilon_{t}$

$\mathrm{INCPAY}_{t}=\lambda_{1} \mathrm{NSI}_{\mathrm{NCS}, t}+\lambda_{2} \mathrm{CS}_{t}+\lambda_{3} \mathrm{GOV}_{t}+\lambda_{4} \mathrm{NSI}_{\mathrm{NCS}, t} \times \mathrm{GOV}_{t}+\lambda_{5} \mathrm{CS}_{t} \times \mathrm{GOV}_{t}$

$$
+\lambda_{6} \mathrm{EBNSI}_{t}+\mathrm{CONTROLS}_{t}+\mathrm{FE}+\varepsilon_{t}
$$

These regressions are estimated for the full sample (1995-2012). They capture the long-term relation between managers' incentive for classification shifting and boards' tolerance for compensation shielding, conditional on firm characteristics and operating environment. We examine $\mathrm{H} 1$ by testing if $\delta_{3}$, the coefficient on NSI $\times \mathrm{GOV}$, is negative. Our hypothesis on compensation shielding, $\mathrm{H} 2$ examines if $\lambda_{5}$, the coefficient on $\mathrm{CS} \times \mathrm{GOV}$, is negative.

\section{Empirical results}

\section{Description of sample}

Panel A of Table 1 summarizes the sample selection procedure. We obtain financial data from the Compustat/CRSP merged dataset, stock return data from CRSP, data on boards of directors and compensation committees from RiskMetrics, institutional ownership data from Thompson Financial, and CEO compensation data from ExecuComp. We merge the ExecuComp CEO data with data from the Compustat/CRSP merged file. IRRC/Riskmetrics began reporting on director independence in 1995, so we further restrict our sample period to 1995-2012. Following 
McVay (2006), we exclude firm-years that have sales of less than one million dollars. Since the estimation of unexpected operating income requires industry-year regressions, we delete observations pertaining to industry-years with less than 15 observations (McVay 2006). We identify the CEO as the person in office for at least six months of a fiscal year using the tags available in ExecuComp. In the case of duplicate CEOs for a year, we select the person that received the largest total annual compensation. To allow for firm-fixed effects, firm-years must have both current- and prior-year data for all of the variables used in Equations 1 to 4 . The final sample consists of 2,244 firms and 16,795 observations during the period 1995-2012. All continuous variables are winsorized at the $1^{\text {st }}$ and $99^{\text {th }}$ percentiles. Panels B and C of Table 1 provide the number of firm-year observations for each industry and each fiscal year.

Table 2 provides descriptive statistics for variables used in the cross-sectional regressions (our largest sample). Panel A reports the median of CEO total incentive pay is $\$ 1.51$ million, while median earnings before negative special items deflated by sales, EBNSI, are 6.5 percent and median annual stock returns, RET, are 8.7 percent. Unexpected core earnings, UE_CE, average $2 \%$ of sales and $1.6 \%$ of sales for the McVay and Fan et al. models. Negative special items, NSI, average $2.1 \%$ of sales, and in more than half (exactly, 52.7 percent) of the total observations, NSI is positive, suggesting that reporting negative special items is common. ${ }^{19}$ In 30.2 percent of the total observations, the proxy for classification shifting, $\mathrm{CS}$, is positive. ${ }^{20}$ The variable, $\mathrm{IND}_{\mathrm{BD}}$ is a count, for each firm-year, whether the audit committee, compensation committee, and overall board structure meets thresholds for independence (see Appendix A). More than half of the firm-

\footnotetext{
${ }^{19}$ NSIs represent a mixing together of losses and gains (such as gains on sale of assets) but losses have greater magnitude than gains. Therefore, $\mathrm{NSI}_{\mathrm{NCS}}$ can be positive or negative.

${ }^{20}$ Untabulated results indicate that approximately 44 percent of misclassified negative special items in year $t-1$ reoccur in year $t$ compared with 68 percent for total negative special items. About 60\% (4992/8387) of negative restructuring charges are associated with classification shifting, CS, in the first year of a restructuring, while about $40 \%$ measure a positive CS on recurrence $(2026 / 5701)$.
} 
year observations are characterized by independence on all three dimensions.

Panel B shows differences in means of key variables between the pre- and post-SOX periods where the post-SOX period is further decomposed into the pre- and post-crisis periods. CEO total incentive pay, firm size, and corporate governance variables display an increasing trend, while accounting and market performance variables have fluctuated with the boom and bust periods that coincide with the pre- and post- SOX periods. Despite FAS 146, classification-shifted expenses, CS, are statistically indistinguishable, pre- and post-2002.

We estimate the difference-in-differences results using smaller samples ranging from 2,218 to 3,208 observations. Panel C provides some descriptive information on the compensation committee partitions in the pre-SOX period. The firms with the least independent compensation committees are somewhat smaller than their control sample, i.e., based on the mean log of total assets (7.304 versus 7.572), and somewhat less profitable (i.e., mean EBNSI is 6.6\% versus 7.4\%). The log of total incentive pay, INCPAY, is also smaller for the non-compliant group (1.006 versus 1.204), consistent with this groups' smaller asset base. The group of firms with highest independence in the pre-SOX period have statistically larger NSI (0.020 versus 0.015$)$, and have larger CS (0.025 versus 0.020$)$. Other group differences are not statistically significant.

Note that the difference-in-differences approach allows the two groups of firms to differ from one another in the pre-SOX and post-SOX period, but valid tests depend on the model being complete. To the extent the two groups are dissimilar, the dissimilarities are captured by control variables. We also assume that these control variables are mapped to the dependent variable via the linear specification we use.

\section{Base-case regressions for classification shifting and compensation shielding}

Table 3 reports the base-case regression models for classification shifting and for compensation shielding. In Panel A, Columns (a) and (b) show that regressing UE_CE on NSI $_{t}$ produces a positive and significant coefficient on $\mathrm{NSI}_{t}(0.258)$ for the McVay (2006) model and a 
negative and significant coefficient on $\mathrm{NSI}_{t}(-0.077)$ for the Fan et al. (2010) model. The signs of these coefficients are consistent with the prior two papers, but magnitudes are not directly comparable due to our inclusion of firm- and year-fixed effects. Despite the negative coefficient on NSI, Fan et al. (2010) conclude, using cross-sectional variation in the coefficient on NSI, that classification shifting occurs, e.g., in the fourth quarter of each year, or when accruals management is constrained.

Panel B contains results of estimating the base-case compensation regression (Equation 4). In all columns, the coefficient on earnings before negative special items, EBNSI, is about 0.63. In Column (a), the coefficient on NSI is -0.311 - about half the size of the coefficient on EBNSI ( $t=3.25$ for the difference in coefficients) consistent with partial shielding on average. Though not tabulated, this coefficient is more negative after 2002 implying pay became more sensitive to negative special items in the post-SOX period.

In Columns (b) and (c), NSI is decomposed into the classification-shifted component of negative special items, CS, and the non-classification-shifted component of negative special items, NSI $_{\text {NCS. }}$ The coefficient on CS is more negative than that on NSI $_{\text {NCS }}$ (e.g., -0.452 on CS and 0.208 on $\mathrm{NSI}_{\mathrm{NCS}}$ in column (b)). Tests for coefficient equality reported at the bottom of Table 3 suggest these coefficients are statistically different for the McVay model, but not for the Fan et al. model. ${ }^{21}$ In untabulated results, the absolute value of the coefficient on CS is less than the coefficient on EBNSI for both models, consistent with partial shielding. ${ }^{22}$

Tests of H1 and H2 using a natural experiment

Table 4 contains tests of our main hypotheses using the natural experiment in which the

21 We examined whether compensation shielding is less prevalent when restructuring charges repeat as in Adut et al. We confirm that one-time restructuring charges are shielded more than are restructuring charges in a sequence.

${ }^{22}$ In the period 2003-2012, the coefficient on CS is significantly negative, and its absolute value is insignificantly different from the coefficient on EBNSI. 
stock exchange rulings and SOX reforms imposed independence on our test firms. The table contains six columns representing two different classification schemes (McVay 2006 and Fan et al. 2010) and three different sets of test and control firms (based on audit and compensation committee compliance in the first four columns and total board compliance in the last two).

The evidence in Panel A of Table 4 weakly supports base-level classification shifting: point estimates on NSI are positive across all columns. They are reliably different from zero for the McVay model in Columns (a), (c), and (e), but they are significant for the Fan et al. model only in Column (f). Also, the coefficients on NSI×NCOMPLY do not differ from zero or are negative and statistically significant (Columns (c), McVay and (f), Fan et al.), so we conclude the two groups' have similar shifting behavior in the period leading up to SOX.

Recall that we expect negative coefficients for NSI $\times$ POST and NSI $\times$ NCOMPLY $\times$ POST if classification shifting is reduced as accounting scrutiny increases (H1). While the coefficients on NSI $\times$ POST have negative point estimates, they are statistically significant only for the half of the columns based on Fan et al. (2010) model. ${ }^{23}$ Further, the coefficients on NSI $\times$ NCOMPLY $\times$ POST vary in sign and do not differ from zero. These coefficients capture whether firms with formerly non-independent board firms reduced classification shifting more in the post 2000 period when board independence was mandated. The results fail to support H1.

Overall, aside from the negative tendency in the coefficient on NSI after 2002, there is little support for our first hypothesis that stronger governance is associated with less classification shifting. This result will be surprising to those who believe that audit and compensation

${ }^{23}$ If we replace firm-fixed effects with Fama-French industry effects and employ firm clustering of standard errors, the coefficient on NSI $\times$ Post is negative in all columns. The evidence appears to be contrary to the conjecture in Kolev et al. (2008) that classification shifting of recurring expenses increased following 2002. Rather, our data are more consistent with conclusions drawn by Lee (2014) using a different research method that SFAS 146, through its stricter verification rules around restructuring charges, reduced discretion over restructuring charges (i.e., some readers might say there is weak evidence of less classification shifting.) 
committees with more independence will put more effort into detecting and punishing earning management. As mentioned in Section 2, such an increase in monitoring and penalties can increase pay-performance sensitivity (discussed next), which can indirectly motivate additional earnings management. Hence, $\mathrm{H} 1$ is subject to tension when pay-performance sensitivity can shift in response to better performance measures (see Goldman and Slezak 2006).

While the equilibrium relation between earnings management and incentive contracts provides a plausible explanation for our failure to reject the null, other scenarios are possible. For example, SOX called for greater penalties on types of earnings manipulation (e.g., bonus clawbacks for accounting restatements). Unlike accrual manipulation, classification shifting does not change bottom-line earnings and thus creates a lower risk of restatement; hence, managers could be substituting accrual manipulation for classification shifting to some extent.

Another reason we can fail to reject the null in Panel A, is that the construct for more intense accounting scrutiny — an increase in board independence-may be invalid. For example, firm outsiders may be less able to detect earnings management because they lack firm-specific or industry knowledge; our research design is premised on idea that independent board members are free from the influence of the $\mathrm{CEO}$ and work harder to monitor, but checks and balances may be insufficient. Finally, a failure to reject the null can also be due to measurement error in estimated excessive core earnings, which we discussed in Section 2.

Results of testing $\mathrm{H} 2$ that compensation shielding is less likely for more independent boards are contained in Table 4 Panel B. The coefficient translating earnings before negative special items into incentive compensation ranges between 1.578 (Column (c)) and 1.057 (Column (e)) and is highly significant. ${ }^{24}$ The statistically insignificant coefficients in the first row labelled $\mathrm{NSI}_{\text {NCS }}$ suggest that boards did not penalize or reward executives for this component of negative

\footnotetext{
${ }^{24}$ Assuming a coefficient equal to 1 , a one standard deviation increase in earnings before negative special items (.128) translates into a $\$ 136,553$ pay increase $\left.\left(\left[e^{.128}-1\right) \times 1,000,000\right]\right)$.
} 
special items. The base coefficient on CS, classification-shifted expenses, is positive across all columns and is statistically significant in all but two ((a), and (f)). So, our measure of classification shifting, CS (recall this is excessively positive core earnings) corresponds to an earnings component that translates on average into increased pay for executives.

H2 predicts that pay sensitivity to classification-shifted expenses is reduced post 2002; support for this hypothesis is indicated by the negative and significant coefficients on CS $\times$ POST in all six columns ((a) to (f)). In addition, the negative and statistically significant coefficient on CS $\times$ POST $\times$ NCOMPLY in Columns (a), (b), and (d), provides evidence in support of our hypothesis that strengthening the independence of audit and compensation committees is associated with less compensation-shielding of our proxy for classification-shifted expenses. ${ }^{25}$ The suggested reduction in compensation shielding implies non-trivial pay cuts. Using the coefficients in Column (a), a one standard deviation increase in classification-shifted expenses (5.4\% of annual sales for McVay model, Table 2), in combination with a mandated independent compensation committee, implies a pay cut of approximately $\$ 137,620$ (= 1 million $\times[\operatorname{Exp}(-2.741 \times 0.054)-1])$. The combination of mandated independence along with the post 2002 general effect implies a pay cut of approximately $\$ 230,786(=\$ 1$ million $\times[\operatorname{Exp}((-2.118-2.741) \times 0.054)-1])$.

However, in Columns (e) and (f) containing treatment and control firms based on overall board independence (i.e., requiring more than $50 \%$ of board members to be independent directors), the data suggest no difference across the two groups (i.e., the coefficients on $\mathrm{CS} \times \mathrm{NCOMPLY}$ and $\mathrm{CS} \times \mathrm{POST} \times \mathrm{NCOMPLY}$ are not different from zero.) Of course, overall board requirements are less stringent than committee impendence requirements. This lower standard for independence at the overall board level versus committees provides some rationale for differences in inferences for the last two columns of this table versus the first four columns.

\footnotetext{
${ }^{25}$ The coefficient (-1.375) in Column (c), McVay model, audit committee sample is not quite significant, $t=-1.55$.
} 
This research design relies on the idea that the general effects of SOX affect all firms in the same way through the variable POST. Other governance effects flow through the NCOMPLY interactions. While the model allows SOX to affect the control variables, the coefficients on the control variables are held constant over time and across the test and control firms.

As a robustness check we relaxed some of these model restrictions by allowing the coefficient on earnings before negative special items (EBNSI) to vary with NCOMPLY and POST. This variation on the empirical model allows for SOX-related changes in pay-sensitivity to overall earnings, to flow through EBNSI, along with the changes in pay sensitivity to CS. The unreported results of this estimation support our inferences for Table 4, if independence is defined with reference to compensation committees. That is, expenses suspected of being classificationshifted, CS, receive higher (meaning more negative) pay sensitivity in the post 2002 period, and the effect is larger for firms who faced the largest changes in independence, NCOMPLY. There is also a higher pay sensitivity to CS in general after SOX (i.e., the coefficient on CS $\times$ POST is negative.) For the remaining four sample strategies (i.e., Columns (c)-(f)), there continues to be a general post-SOX reduction in compensation shielding, but there is not an incremental effect for audit committee independence or a single board independence. Also, untabulated results indicate that the pay-sensitivity to EBNSI does not vary statistically, pre- versus post-SOX, or based on committee independence. These results suggest first, that the estimated effects of increased pay sensitivity to classification-shifted expenses are most robust where compliance is defined by compensation committee independence, and second, and that our original specification that constrains the coefficient on EBNSI to be constant is appropriate.

Overall, we interpret the evidence in Table 4 to support $\mathrm{H} 2$ : compensation shielding of classification-shifted expenses is reduced when compensation committees and audit committees are forced to be more independent. The table also suggests that compensation shielding was reduced in conjunction with governance reforms that took place in 2002, regardless of whether or 
not firms were in compliance with board independence requirements.

\section{Cross-sectional tests of $\mathrm{H} 1$ and $\mathrm{H} 2$}

In Table 5 we use a broader measure of corporate governance (formed through factor analysis, GOV) and the full set of sample firm-years described in Table 2. The GOV measure includes a weighting on board independence, but also it intends to capture concepts such as CEO entrenchment, external monitoring, and agency cost magnitudes. This broadened definition of governance affects our inferences regarding H1. In Panel A, the coefficient on NSI $\times$ GOV is significantly negative in both Columns (a) and (b), suggesting that managers engage in classification shifting to a lesser extent when corporate governance is relatively strong. In addition, the results in this table have similar implications to those of Table 5 with regard to compensation shielding; in Panel B the coefficient on $\mathrm{CS} \times \mathrm{GOV}$ is reliably negative, suggesting that well-governed firms are less likely to shield CEO pay from classification-shifted expenses Overall, this cross-sectional test supports both hypotheses.

Contrasting our two main tests of H1, Table 4 finds little evidence in support of H1, Table 5 suggests the opposite. While we cannot be sure the reasons for the differences, it is possible that Table 5 employs a more relevant measure of governance, as applied to classification shifting. ${ }^{26}$ In addition, the number of observations in Table 5 likely adds power to our test.

\section{Additional Analyses}

\section{The role of audit quality}

The governance factors that influence compensation shielding could be different than those influencing classification shifting. One factor overlooked so far is the role of the external auditor. Since negative special items tend to be material, they draw the attention of auditors, and

\footnotetext{
${ }^{26}$ Results using a board independence index (IND ${ }_{\mathrm{BD}}$, instead of GOV) provide consistent evidence to support $\mathrm{H} 2$ but not $\mathrm{H} 1$. See Appendix 2 for definition of IND $\mathrm{BD}_{\mathrm{BD}}$. Because these results are so similar to Table 4, they are not tabulated in the interest of brevity. The results that support classification shifting rely on the broader governance measure, GOV.
} 
this could cause managers to be more conservative in their decision to classification shift. In fact, prior research by Haw et al. (2011) finds a mediating effect of Big 4 audit quality on classification shifting in East Asian countries. We replicate the specification in Table 5 using a change in audit quality indicator to explore the relation between audit quality and classification shifting. We employ changes in audit quality rather than level of audit quality, (i.e., an indicator for Big 4 auditor) because the level is very sticky over time. In our sample there are 785 auditor changes: 663 are auditor changes from a non-Big 4 or from a Big-4 auditor to a (different) Big-4 auditor and 122 are auditor changes from a Big 4 or from a non-Big-4 auditor to a (different) non-Big 4 auditor. $^{27}$ Panel A of Table 6 shows the predicted reduction in classification shifting when firms switched to higher audit quality (NSI $\times$ CH_AUB4), while it shows an increase in classification shifting when audit quality weakens (NSI×CH_AUNB4). ${ }^{28}$

In parallel with other tests, we explored the relation between audit quality changes and pay shielding. Panel B of Table 6 shows evidence that there is less compensation shielding of classification-shifted expenses when audit quality improves (i.e., the coefficient on

$\mathrm{CS} \times \mathrm{CH}$ _AUB4 is negative and significant); however, the coefficients for lower quality, $\mathrm{CS} \times \mathrm{CH} \_$AUNB4 are statistically insignificant. ${ }^{29}$

The role of the extent of overlap between compensation and audit committees

\footnotetext{
${ }^{27}$ Our audit-quality improvement measure includes 82 switches from non-Big-4 to Big-4 along with 616 switches between Big-4 auditors. The idea that switches among Big-4 is indicative of audit quality improvements is somewhat debateable. The proposal that firms should be forced into mandatory rotation of auditors is based on the notion that longer tenure leads to less independence. However, empirically, some studies link higher quality to longer tenure (e.g., Ghosh and Moon 2005). Our audit decrease indicator includes 47 switches from a Big-4 to non-Big 4, and 82 switches between non-Big 4 auditors (e.g., indicating lower quality under opinion shopping). ${ }^{28}$ If we denote high quality auditing using the "sticky" indicator for Big 4 versus non-Big 4, we find a negative influence of high quality auditing on classification shifting but this effect is statistically significant for the Fan et al. (2010) model and not for the McVay (2006) model. ${ }^{29}$ A reviewer suggested we investigate excess audit fees and their relation to our two hypotheses. We used the approach in Choi, Kim, Kim and Zang (2010). The results reveal coefficients opposite to $\mathrm{H} 1$ and H2. Perhaps excess audit fees are a proxy for auditor client bonding.
} 
Cross-membership of a board's compensation and audit committees (hereafter, overlapping membership) could relate to classification shifting or compensation shielding. Our prior beliefs were that overlapping membership would enable a valuable transfer of accounting information from the audit function to the compensation function (and vice versa), thereby assisting in mitigating moral hazard by the CEO. However, Laux and Laux (2009) provide assumptions for which overlapping membership leads to a moral hazard condition for the audit committee members. In Laux and Laux, the best governance structure would avoid committee membership overlaps to reduce the effects of this moral hazard. ${ }^{30}$ We explore whether overlapping membership affects compensation shielding, and whether this is mediated by strongly independent members on the audit committee (who, we assume are less subject to the moral hazard problem raised in Laux and Laux.)

We form an indicator variable for relatively high overlapping membership (AUDCOMP), which equals one if the percentage of compensation committee members with overlapping membership on the audit and compensation committees exceeds the sample median and zero otherwise. ${ }^{31} \mathrm{We}$ also measure an indicator variable for an independent audit committee, $\mathrm{IND}_{\mathrm{AUD}}$, which equals one if all audit committee members are independent directors and attend more than $75 \%$ of board meetings. We are uncertain if AUDCOMP will increase or decrease classification shifting and (or) shielding. An increase would be consistent with Laux and Laux. We predict, as in prior tables that independent board members will lead to less compensation shielding and classification shifting.

\footnotetext{
${ }^{30}$ Laux and Laux assume audit committee members internalize a personal effort cost in their role as overseers of accounting, whereas the compensation committee members do not have an analogous personal cost. If a board member sits on both committees, moral hazard costs are increased due to this board member's inability to treat the audit effort cost at arms-length. ${ }^{31}$ As shown in Table 7 by the +/- prediction, we are uncertain whether AUDCOMP should increase shifting and compensation shielding (consistent with Laux and Laux) or, if this should decrease shifting and compensation shielding consistent with efficient information transfer.
} 
Table 7, Panel A, suggests the effects of overlapping membership and independence on classification shifting are statistically significant for McVay model, but are insignificant under the Fan et al. These inconsistencies make us unwilling to draw conclusions. Panel B shows the data support a negative coefficient on $\mathrm{IND}_{\mathrm{AUD}} \times \mathrm{CS}$, consistent with $\mathrm{H} 2$. In addition, the three-way interaction term $\mathrm{CS} \times \mathrm{IND}_{\mathrm{AUD}} \times \mathrm{AUDTCOMP}$ has a negative coefficient, suggesting that the influence of monitoring by the independent audit committee on compensation shielding is more effective when there is a higher overlapping membership. However, the positive coefficient on CS $\times$ AUDCOMP is consistent with Laux and Laux's model that a higher overlapping membership provides less effective board oversight. Overall, we conclude that any synergistic effect of overlapping membership on compensation shielding is amplified by the presence of independent and hardworking audit committee members.

Using CFO total incentives as an alternative dependent variable

Our tabulated results focus on CEOs rather than CFOs. This enhances comparability with prior studies on compensation shielding. Moreover, CEOs who have overall responsibility for firm performance are likely to have more influence over the strategic decisions that lead to negative special items (e.g., restructuring.) In addition, they exert control over financial reporting by monitoring and rewarding the activities of CFOs. However, CFOs can also possibly obtain personal financial gain through classification shifting. To examine this idea, we follow Jiang et al. (2010) to identify CFOs and re-estimate Panels A of Tables 4 to 5 using CFO level data. We find no statistically significant support for our main hypotheses.

The effect of say-on-pay voting

Another regulatory focus in our sample period has been CEO pay. In 2006, the SEC adopted new requirements in proxy statements to disclose more components of pay. In addition, mandated but non-binding initiatives for shareholder opinions on pay were implemented in 2010. We examined whether compensation shielding is related to shareholder sentiment on pay, 
confirming that more favorable votes are associated with lower pay overall, but finding no interactive effects with negative special items. ${ }^{32}$

\section{Conclusion}

Annual compensation for top executives responds more to earnings before special items than to the unusual or infrequent charges that comprise special items. In this paper, we start with the premise that the practice of shielding executive compensation from these unusual or infrequent charges provides an incentive for top managers to overstate special items and influence current pay. We examine whether executives appear to vertically shift current expenses into special items for the pay side-effect, and also whether strong corporate governance mediates either the classification shifting behavior or the pay consequences of classification shifting (aka compensation shielding). Corporate governance reforms that took place in 2002 provide a quasiexperimental design to address the empirical challenge that governance structure is endogenously assigned to corporations. We present two hypotheses: first, that stronger governance reduces a firm's engagement in classification shifting, and second, that stronger governance leads to less compensation shielding. However, agency theoretic models of the interplay between governance, pay-performance sensitivity and earnings management provide arguments suggesting that these hypotheses are subject to tension. These models do not predict unambiguously that earnings management will decrease following improvements in detection and increasing penalties for manipulation of performance.

Using two different research design strategies, the quasi-experiment and cross-sectional tests, we find evidence consistent with our second hypothesis (that stronger governance is less willing to pay for classification-shifted expenses), but mixed evidence for the first hypothesis (that stronger governance reduces classification shifting magnitudes). The data support the idea that

\footnotetext{
${ }^{32}$ We borrowed hand-collected data on the voting outcomes for a set of 1,129 firms from Jenny Zhang and Shuo Yang.
} 
firms are less willing to protect CEO pay from classification-shifted expenses after SOX, and this effect is more intense for firms that experienced a mandated increase in audit and compensation committee independence. These results are strongest if governance is captured by compensation committee independence, as opposed to audit committee independence or general board independence. The results for pay-shielding are supported by additional cross-sectional analysis using an alternative measure of governance.

Using the quasi-experiment, the data do not suggest that board, or committee independence reduces classification shifting per se or that classification shifting is reduced post 2002. As a matter of fact, audit committee independence is not a predictor of lower classification shifting. This result, while not inconsistent with theory, could arise from a variety of real-world deviations from theory. One possibility is that independent audit committee members lack the firm-specific knowledge to make the audit function more precise. On the other hand, when we use a broader measure of governance, expanded to include weightings on other proxies for monitoring, we find that stronger governance in the cross-section is associated with less classification shifting. Also, changes in audit quality, either improving or degrading, are associated as predicted with classification shifting.

These cross-sectional findings are intriguing, but the lack of correspondence in results with the quasi-experiment is unsettling. Foremost, the measurement of classification shifting is challenging, so the failure to reject the null for our first hypothesis (that classification shifting is unaffected by strong governance) is difficult to interpret. In fact, measurement error alone could lead to low power tests. Often the classification shifting results vary depending on which model (McVay 2006 or Fan et al. 2010) that we use. In the end, we resist drawing strong conclusions regarding the effects of governance on classification shifting. 


\section{References}

Adut, D., W. Cready, and T. Lopez. 2003. Restructuring charges and CEO cash compensation: A reexamination. The Accounting Review 78(1): 169-192.

Armstrong, C. S., J. E. Core, and W.R. Guay. 2014. Do independent directors cause improvements in firm transparency? Journal of Financial Economics 113(3): 383 - 403.

Beatty, A. and J. Weber. 2006. Accounting discretion in fair value estimates: An examination of SFAS 142 goodwill impairments. Journal of Accounting Research 44(2): 257-288.

Bens, D. A. and R. Johnston. 2009. Accounting discretion: use or abuse? An analysis of restructuring charges surrounding regulator action. Contemporary Accounting Research 26(3): 673-699.

Bergstresser, D. and T. Philippon. 2006. CEO incentives and earnings management. Journal of Financial Economics 80(3): 511-529.

Burns, N. and S. Kedia. 2006. The impact of performance-based compensation on misreporting. Journal of Financial Economics 79(1): 35-67.

Bushee, B. J. 1998. The influence of institutional investors on myopic R\&D investment behavior. The Accounting review 73(3): 305-333.

Carter, E. M., L. J. Lynch, and S. L. Zechman. 2009. Changes in bonus contracts in the postSarbanes-Oxley era. Review of Accounting Studies 14(4): 480-506.

Cheng, Q. and T. D. Warfield. 2005. Equity incentives and earnings management. The Accounting Review 80(2): 441-476.

Cheng, Q., X. Chen, and X. Wang. 2015. Does increased board independence reduce earnings management? Evidence from recent regulatory reforms. Review of Accounting Studies 20(2): 899-933.

Chhaochharia, V. and Y. Grinstein. 2009. CEO compensation and board structure. Journal of Finance 64(1): 231-261.

Choi, J. H., C. Kim, J. B. Kim, and Y. Zang. 2010. Audit office size, audit quality, and audit pricing. Auditing: A Journal of Practice \& Theory 29(1): 73-97.

Cohen, D. A., A. Dey, and T. Lys. 2008. Real and accrual-based earnings management in the preand post-Sarbanes-Oxley periods. The accounting review 83(3): 757-787.

Core, J. E., R. W. Holthausen, and D. F. Larcker. 1998. Corporate governance, chief executive officer compensation, and firm performance. Journal of Financial Economics 51(3): 371-406.

DeAngelo, H., L. DeAngelo, and D. Skinner. 1994. Accounting choice in troubled companies. Journal of Accounting and Economics 17(1-2): 113-143.

Dechow, P., M. Huson, and R. Sloan. 1994. The effect of restructuring charges on executives' cash compensation. The Accounting Review 69(1): 138-156.

Donelson, D., J. McInnis, and R. Mergenthaler. 2015. The effect of governance reforms on financial reporting fraud. Journal of Law, Finance \& Accounting, Forthcoming.

Duchin, R., J. G. Matsusaka, and O. Ozbas. 2010. When are outside directors effective? Journal of Financial Economics 96(2): 195-214. 
Dutta, S. and Q. Fan. 2014. Equilibrium earnings management and managerial compensation in a multiperiod agency setting. Review of Accounting Studies 19(3): 1047-1077.

Ewert, R. and A. Wagenhofer. 2005. Economic effects of tightening accounting standards to restrict earnings management. The Accounting Review 80(4): 1101-1124.

Fama, E, F. and K. R. French. 1997. Industry costs of equity. Journal of Financial Economics 43(2): 153-193.

Fan, Y., A. Barua, W. M. Cready, and W. B. Thomas. 2010. Managing earnings using classification shifting: evidence from quarterly special items. The Accounting Review 85(4): 1303-1323.

Francis, J., J. D. Hanna, and L. Vincent. 1996. Causes and effects of discretionary asset write-offs. Journal of Accounting Research 34: 117-134.

Gaver, J. and K. Gaver. 1998. The relation between nonrecurring accounting transactions and CEO cash compensation. The Accounting Review 73(2): 235-253.

Gaver, J., K. Gaver, and J. Austin. 1995. Additional evidence on bonus plans and income management. Journal of Accounting and Economics 19(1): 3-28.

Goldman, E. and S. L. Slezak. 2006. An equilibrium model of incentive contracts in the presence of information manipulation. Journal of Financial Economics 80(3): 603-626.

Ghosh, A., and Doocheol Moon. 2005. Auditor tenure and perceptions of audit quality. The Accounting Review 80(2): 585-612.

Hartzell, J., and L. Starks. 2003. Institutional investors and executive compensation. Journal of Finance 58(6): 2351-2374.

Haw, In-Mu, S. Ho, and Y. Li. 2011. Corporate governance and earnings management by classification shifting. Contemporary Accounting Research 28(2): 517-553.

Healy, P. 1985. The effect of bonus schemes on accounting decisions. Journal of Accounting and Economics 7: 85-107.

Holthausen, R., D. Larcker, and S.G. Sloan. 1995. Annual bonus schemes and the manipulation of earnings. Journal of Accounting and Economics 19(1): 29-74.

Jiang, J., K. Petroni, and I. Wang. 2010. CFOs and CEOs: who have the most influence on earnings management? Journal of Financial Economics 96(3): 513-526.

Klein, A. 2002. Audit committee, board of director characteristics, and earnings management. Journal of Accounting and Economics 33(3): 375-400.

Klein, A. 2003. Likely effects of stock exchange governance proposals and Sarbanes-Oxley on corporate boards and financial reporting. Accounting Horizons 17(4). 343-355.

Kolev, K., C. Marquardt, and S. E. McVay. 2008. SEC scrutiny and the evolution of non-GAAP reporting. The Accounting Review 83(1): 157-184.

Laux, C. and V. Laux. 2009. Board committees, CEO compensation, and earnings management The Accounting Review 84(3): 869-891.

Lee, Y. G. 2014. An examination of restructuring charges surrounding the implementation of SFAS 14. Review of Accounting Studies 19(2): 539-572. 
Leone, A. J., J. S. Wu, and J. L. Zimmerman. 2006. Asymmetric sensitivity of CEO cash compensation to stock returns. Journal of Accounting and Economics 42(1): 167-192.

McVay, S. E. 2006. Earnings management using classification shifting: An examination of recurring earnings and special items. The Accounting Review 81(3): 501-531.

Nissim, D. and S. Penman. 2001. Ratio analysis and equity valuation. Review of Accounting Studies 6(1): 109-154.

Riedl, E. J. 2004. An examination of long-lived asset impairments. The Accounting Review 79(3): 823-852.

Sloan, R. G. 1996. Do stock prices fully reflect information in accruals and cash flows about future earnings? The Accounting Review 71(3): 289-315. 


\section{Appendix 1}

Examples of the disclosure of the adjustment of performance measures in recognition of unusual or infrequent events (i.e., special items)

Case 1: GENERAL ELECTRIC (proxy statement for 2007)

"For payment of long-term performance awards granted under the 2007 Plan, the company would use one or more of the following business measurements: sales, revenue, net income, net earnings, earnings per share, return on total capital, return on equity, cash flow, operating profit, and margin rate, subject to adjustment by the MDCC to remove the effect of charges for restructurings, discontinued operations, extraordinary items, and all items of gain, loss or expense determined to be extraordinary or unusual in nature or infrequent in occurrence, related to the disposal of a segment or a business, or related to a change in accounting principle or otherwise. The MDCC may establish performance goals that are measured either individually, alternatively or in any combination, applied to either the company as a whole or to a business unit or related company, and measured either annually or cumulatively over a period of years, on an absolute basis or relative to a pre-established target, to a previous year's results or to a designated comparison group, in each case as specified by the MDCC in the award" [emphasis mine].

Case 2: WASHINGTON MUTUAL, INC. (Proxy statement for year 2008)

\section{Bonus Plan Design}

"The Committee varies the performance measures and the weights assigned to each performance measure from year to year based on current year business objectives. For 2008 bonuses the Committee selected the following performance measures and relative weights which apply to executives and almost 3,000 of our senior managers: net operating profit: 30 percent, noninterest expense: 25 percent, depositor and other retail banking fees: 25 percent, and customer loyalty: 20 percent. Net operating profit will be calculated before income taxes and excluding the effects of loan loss provisions other than related to our credit card business and expenses related to foreclosed real estate assets. Noninterest expense will be calculated excluding expenses related to business resizing or restructuring and expenses related to foreclosed real estate assets. For each of these performance measures, the Committee established a range of achievement levels from zero to 150 percent of target. Like the 2007 plan, the 2008 Leadership Bonus Plan bonus payout targets range up to 365 percent of 2008 base salary, depending on position. In evaluating financial performance, the Committee may adjust results to eliminate the effects of charges for restructurings, discontinued operations, extraordinary items and items of gain, loss or expense determined to be extraordinary or unusual in nature or infrequent in occurrence or related to the disposal of a segment or a business or related to a change in accounting principle" [emphasis mine]. 


\section{Appendix 2 Definition of Variables}

$$
\begin{aligned}
& \text { Determinants of expected core earnings } \\
& \mathrm{CE}_{t-k} \quad=\text { Core earnings deflated by sales for year } t-\mathrm{k}(\mathrm{k}=0,1) \text {, measured as } \\
& \text { operating income before depreciation (COMPUSTAT oibdp) } \\
& \mathrm{ATO}_{t} \quad=\text { Operating asset turnover for year } t \text {, which is measured as sales divided by } \\
& \text { average net operating asset } \\
& \text { Accruals }_{t-k} \quad=\text { Total accruals in year } t-\mathrm{k}(\mathrm{k}=0,1) \text {, which is earnings before extraordinary } \\
& \text { items less cash flows from operating activities deflated by sales } \\
& \Delta \text { SALES }_{t} \quad=\text { Sales growth rate for year } t \text {, which is measured as }\left(\text { sales }_{t}-\text { sales }_{t-1}\right) / \text { sales }_{t-1} \\
& \mathrm{NEG} \triangle \mathrm{SALES}_{t}=\Delta \mathrm{SALES}_{t} \text { if less than zero and zero otherwise } \\
& \text { RET }_{t} \quad=\text { Annual stock returns (including dividends) for year } t \\
& \operatorname{RET}_{t-1} \quad=\text { Annual stock returns (including dividends) for year } t-1
\end{aligned}
$$

\begin{tabular}{|c|c|}
\hline $\mathrm{INCPAY}_{t}$ & $\begin{array}{l}=\text { The logarithm of one plus total incentive pay awarded to CEO based on } \\
\text { year } t \text { firm performance. Total incentive pay includes cash incentive and } \\
\text { equity grants. Cash incentive is measured as the sum of the annual bonus } \\
\text { and non-equity incentive plan. The missing values for the non-equity } \\
\text { incentive plan before } 2006 \text { are replaced with long-term incentive payout } \\
\text { (ExecuComp ltip). Equity grants are the sum of stock grants and option } \\
\text { grants. An inflation adjustment is made to } 2000 \text { constant dollars based on } \\
\text { the consumer price index published by the Bureau of Labor Statistics. }\end{array}$ \\
\hline $\mathrm{EBNSI}_{t}$ & $\begin{aligned}= & \text { Income before extraordinary items and results of discontinued operations } \\
& \text { plus negative special items deflated by sales for year } t\end{aligned}$ \\
\hline STDEBNSI $_{t}$ & $=$ Standard deviation of $\mathrm{EBNSI}_{t}$ during the period $t-5$ to $t-1$ \\
\hline $\mathrm{RET}_{t}$ & $=$ Annual stock returns (including common dividends) for year $t$ \\
\hline $\mathrm{D}_{\mathrm{NEG}, t} \times \mathrm{RET}_{t}$ & $=$ Negative annual stock returns for year $t$ \\
\hline $\mathrm{STDRET}_{t}$ & $=$ Standard deviation of $\mathrm{RET}_{t}$ during the period $t-5$ to $t-1$ \\
\hline $\mathrm{INVOPP}_{t}$ & $\begin{aligned}= & \text { Investment opportunity at the start of year } t \text {, which is measured as the five- } \\
& \text { year average of the market-to-book total asset ratio for the period } t-5 \text { to } \\
& t-1 \text {. The market value of total assets is the book value of total assets minus }\end{aligned}$ \\
\hline
\end{tabular}

\section{Classification shifting measures}

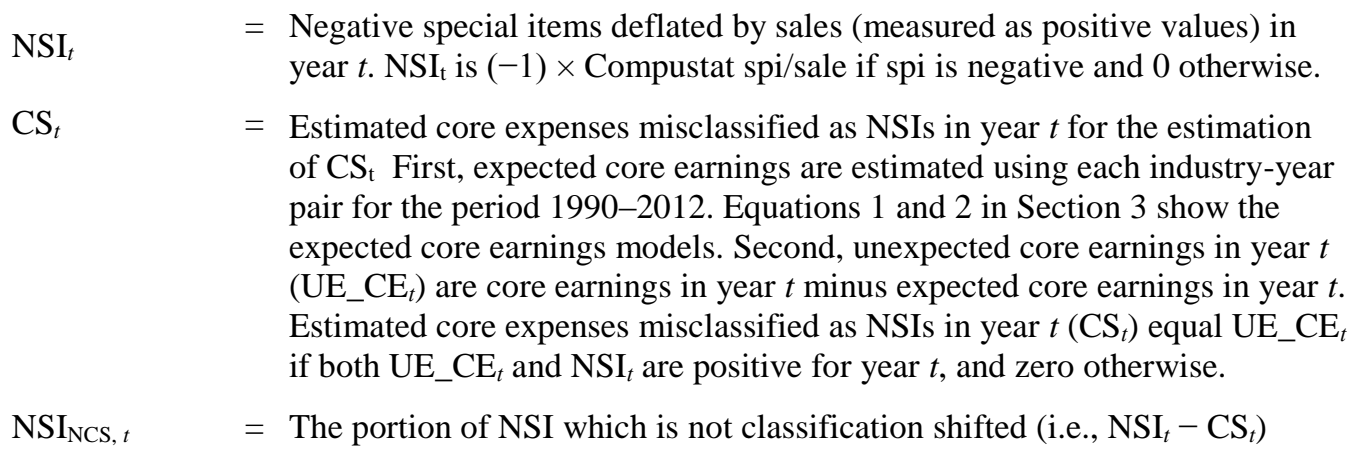

Executive compensation 
the book value of common equity plus the market value of common equity

LOGASSETS $_{\mathrm{t}}=$ The logarithm of lagged total assets in inflation-adjusted dollars

Corporate governance variables

$\mathrm{NCOMPLY}_{t}=$ An indicator for all firms that had not complied with the SOX provision on the independence of the board of directors and its compensation or audit

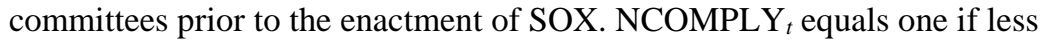
than $100 \%$ of committee members (50\% of board members) are independent directors and zero otherwise at the first shareholders' meeting occurring after the end of year 1999, and these firms had met the noncompliance condition at the first shareholders meetings held after the end of 2000 and 2001, respectively.

$\mathrm{POST}_{t}=$ An indicator variable for the post-SOX period which equals one for the 2003-2006 period and zero for the period 1995-2001 period

$\mathrm{IND}_{\mathrm{BD}, t}=$ An index for overall independence of board and committees. $\mathrm{IND}_{\mathrm{BD}, t}=$ $\mathrm{IND}_{\mathrm{COMP}, t}+\mathrm{IND}_{\mathrm{AUD}, t}+\mathrm{IND}_{\mathrm{BOARD}, t}$, where an indicator for compensation (audit) committee independence, $\operatorname{IND}_{\mathrm{COMP}, t}\left(\operatorname{IND}_{\mathrm{AUD}, t}\right)$, is one if all committee members are independent directors (IRRC 'I') and attend more than $3 / 4$ of board meetings in a year, and zero otherwise; and an indicator

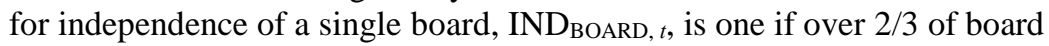
members are independent directors and attend more than $3 / 4$ of board meetings in a year, and zero otherwise

$\mathrm{GOV}_{t} \quad=$ A corporate governance index based on a factor analysis of the characteristics of boards and executive officers and ownership structure. Board and management attributes include CEO duality, board size, the percentage of independent directors in a board, the percentage of independent directors over age 69, and the percentage of busy independent directors (Core et al. 1998). Ownership structure includes CEO ownership as a percentage of number of shares outstanding, the existence of non-CEO insiders with ownership over $5 \%$, the number of outside block-holders with ownership over $5 \%$, and institutional investors' ownership as a percentage of number of shares outstanding (Core et al. 1998; Bushee 1998; Hartzell and Stark 2003). Standardized scoring coefficients are as follows:

$0.173 *$ CEO duality $+0.427 *$ Percentage of independent directors +0.195 *Board size $-0.002 *$ Percentage of old independent directors + $0.297 *$ Percentage of busy independent directors $-0.273 *$ CEO ownership $0.002 *$ The number of block holders with $5 \%$ ownership + $0.125 *$ Institutional ownership $-0.401 *$ An indicator for non-CEO insiders with 5\% ownership.

CH_AUB $4_{t}=$ An indicator for an auditor change from a non-Big 4 or from a Big 4 audit firm to a Big 4 audit firm (Deloitte, PWC, EY, KPMG)

CH_AUNB4 $t_{t}=$ An indicator for an auditor change from a non-Big 4 firm or from a Big 4 audit firm to a non-Big 4 audit firm

AUDCOMP $_{t}=$ An indicator for high overlapping membership, which equals one if the percentage of compensation committee members who are audit committee members exceeds its sample median and zero otherwise 
TABLE 1

Sample selection and sample distribution

Panel A: Sample selection procedures

\begin{tabular}{lc}
\hline Description & $\mathrm{N}$ \\
\hline $\begin{array}{l}\text { All the firm-years of ExecuComp CEO data and IRRC/Riskmetrics data merged } \\
\text { with the data derived from the annual COMPUSTAT/CRSP merged file for the } \\
\text { period 1995-2012 }\end{array}$ & 32,669 \\
Less: Firm-years lacking & \\
$\begin{array}{l}\text { Current and lagged values in the log of one plus total compensation, the log of one } \\
\text { plus cash compensation, and the logarithm of one plus the cash incentive }\end{array}$ & $(2,391)$ \\
$\begin{array}{l}\text { Current and lagged values in annual stock returns, earnings before NSIs, and the } \\
\text { natural logarithm of sales }\end{array}$ & $(1,689)$ \\
$\begin{array}{l}\text { Current and lagged values in the standard deviation of annual stock returns, earnings } \\
\text { before negative special items, and investment opportunities }\end{array}$ & $(10,793)$ \\
Current and lagged values in correctly classified and misclassified NSIs & $(1,001)$ \\
Final sample (1995-2012) & 16,795 \\
\hline
\end{tabular}

Panel B: Sample distribution by the Fama and French (1997) 48 industries

\begin{tabular}{lcclcc}
\hline \multicolumn{1}{c}{ Industry } & $\mathrm{N}$ & $\%$ & & $\mathrm{~N}$ & $\%$ \\
\hline Business service & 1,644 & 9.8 & Computers & 502 & 3.0 \\
Utilities & 1,247 & 7.4 & Measuring \& control equipment & 489 & 2.9 \\
Retail & 1,211 & 7.2 & Chemicals & 465 & 2.8 \\
Electronic equipment & 1,164 & 6.9 & Laboratory equipment & 424 & 2.5 \\
Pharmaceutical products & 765 & 4.6 & Telecommunication & 393 & 2.3 \\
Petroleum and natural gas & 737 & 4.4 & Restaurants, hotel, motel & 384 & 2.3 \\
Machine \& equipment & 696 & 4.1 & Finance & 383 & 2.3 \\
Insurance & 603 & 3.6 & Food & 382 & 2.3 \\
Transportation & 532 & 3.2 & Paper & 381 & 2.3 \\
Wholesale & 526 & 3.1 & Other industries & 3,867 & 23.0 \\
\hline
\end{tabular}

Panel C: Sample distribution by fiscal year $(\mathrm{N}=16,795)$

\begin{tabular}{ccccccccc}
\hline Year & $\mathrm{N}$ & $\%$ & Year & $\mathrm{N}$ & $\%$ & Year & $\mathrm{N}$ & $\%$ \\
\hline 1995 & 631 & 3.8 & 2001 & 873 & 5.2 & 2007 & 1,021 & 6.1 \\
1996 & 698 & 4.2 & 2002 & 922 & 5.5 & 2008 & 1,025 & 6.1 \\
1997 & 718 & 4.3 & 2003 & 974 & 5.8 & 2009 & 1,085 & 6.5 \\
1998 & 773 & 4.6 & 2004 & 996 & 6.0 & 2010 & 1,104 & 6.6 \\
1999 & 846 & 5.0 & 2005 & 1,004 & 6.0 & 2011 & 1,116 & 6.6 \\
2000 & 868 & 5.2 & 2006 & 1,014 & 6.0 & 2012 & 1,127 & 6.7 \\
\hline
\end{tabular}


TABLE 2

Descriptive statistics

Panel A: Summary statistics over total sample period

\begin{tabular}{|c|c|c|c|c|c|c|c|c|}
\hline Variable & $\mathrm{N}$ & Mean & SD & $5 \%$ & $25 \%$ & $50 \%$ & $75 \%$ & $95 \%$ \\
\hline \multicolumn{9}{|l|}{ Compensation } \\
\hline $\begin{array}{l}\text { CEOINCPAY }_{t} \\
(\mathrm{mil} \$)\end{array}$ & 16,795 & 3.279 & 9.312 & 0.000 & 0.526 & 1.514 & 3.685 & 11.10 \\
\hline $\begin{array}{l}\mathrm{INCPAY}_{t} \\
(\log \text { of } 1+\text { mil } \$)\end{array}$ & 16,795 & 1.048 & 0.790 & 0.000 & 0.423 & 0.922 & 1.544 & 2.493 \\
\hline EBNSI $_{t}$ & 16,795 & 0.063 & 0.128 & -0.084 & 0.030 & 0.065 & 0.112 & 0.231 \\
\hline STDEBNSI $_{t}$ & 16,795 & 0.119 & 0.297 & 0.008 & 0.020 & 0.040 & 0.092 & 0.413 \\
\hline $\operatorname{RET}_{t}$ & 16,795 & 0.140 & 0.489 & -0.537 & -0.148 & 0.087 & 0.336 & 1.009 \\
\hline $\mathrm{RET}_{t} \mathrm{D}_{\mathrm{NEG}, t}$ & 16,795 & -0.106 & 0.187 & -0.537 & -0.148 & 0.000 & 0.000 & 0.000 \\
\hline $\mathrm{STDRET}_{t}$ & 16,795 & 0.966 & 0.855 & 0.255 & 0.463 & 0.716 & 1.125 & 2.629 \\
\hline LOGASSETS $_{t}$ & 16,795 & 7.230 & 1.617 & 4.787 & 6.056 & 7.077 & 8.260 & 10.149 \\
\hline $\mathrm{INVOPP}_{t}$ & 16,795 & 2.017 & 1.370 & 0.971 & 1.191 & 1.571 & 2.309 & 4.699 \\
\hline \multicolumn{9}{|l|}{ Special items } \\
\hline $\mathrm{NSI}_{t}$ & 16,795 & 0.021 & 0.057 & 0.000 & 0.000 & 0.001 & 0.013 & 0.103 \\
\hline $\mathrm{UE}_{-} \mathrm{CE}_{t}$ (McVay) & 16,795 & 0.020 & 0.131 & -0.099 & -0.019 & 0.008 & 0.047 & 0.186 \\
\hline $\mathrm{CS}_{\mathrm{t}}$ (McVay) & 16,795 & 0.021 & 0.054 & 0.000 & 0.000 & 0.000 & 0.012 & 0.129 \\
\hline $\mathrm{NSI}_{\mathrm{NCS}, t}$ (McVay) & 16,795 & -0.001 & 0.058 & -0.086 & 0.000 & 0.000 & 0.003 & 0.066 \\
\hline UE_CE $E_{t}$ (Fan et al.) & 16,795 & 0.016 & 0.141 & -0.102 & -0.019 & 0.006 & 0.043 & 0.177 \\
\hline $\mathrm{CS}_{t}$ (Fan et al.) & 16,795 & 0.019 & 0.050 & 0.000 & 0.000 & 0.000 & 0.009 & 0.117 \\
\hline $\mathrm{NSI}_{\mathrm{NCS}, t}($ Fan et al. $)$ & 16,795 & 0.001 & 0.064 & -0.084 & 0.000 & 0.000 & 0.003 & 0.074 \\
\hline \multicolumn{9}{|l|}{ Governance } \\
\hline $\mathrm{IND}_{\mathrm{BD}, t}$ & 11,667 & 2.125 & 1.052 & 0.000 & 1.000 & 3.000 & 3.000 & 3.000 \\
\hline $\mathrm{GOV}_{t}$ & 9,878 & 0.044 & 0.965 & -1.887 & -0.415 & 0.192 & 0.691 & 1.356 \\
\hline $\mathrm{AUDCOMP}_{t}$ & 11,671 & 0.615 & 0.487 & 0.000 & 0.000 & 1.000 & 1.000 & 1.000 \\
\hline $\mathrm{CH} \_\mathrm{AUB} 4_{t}$ & 16,795 & 0.040 & 0.195 & 0.000 & 0.000 & 0.000 & 0.000 & 0.000 \\
\hline $\mathrm{CH} \_\mathrm{AUNB} 4_{t}$ & 16,795 & 0.007 & 0.086 & 0.000 & 0.000 & 0.000 & 0.000 & 0.000 \\
\hline
\end{tabular}

Note: See Appendix 2 for definitions of variables in this table. 
TABLE 2 (Continued)

Panel B: Summary statistics by pre- and post-SOX periods

\begin{tabular}{|c|c|c|c|c|c|}
\hline \multirow[b]{2}{*}{ Variables } & \multirow{2}{*}{$\begin{array}{c}\text { (a) } \\
\text { Pre-SOX } \\
(95-02)\end{array}$} & \multicolumn{2}{|c|}{ Post-Sox (03-12) } & \multicolumn{2}{|c|}{ Mean differences } \\
\hline & & $\begin{array}{c}\text { (b) } \\
\text { Pre-crisis } \\
(03-07)\end{array}$ & $\begin{array}{c}(\mathrm{c}) \\
\text { Post-crisis } \\
(08-12)\end{array}$ & $(b-a)$ & $(c-b)$ \\
\hline $\begin{array}{l}\text { INCPAY }_{t} \\
\text { (log 1+mil.) }\end{array}$ & 0.948 & 1.093 & 1.123 & $0.145^{* * *}$ & $0.030^{* * * *}$ \\
\hline EBNSI $_{t}$ & 0.056 & 0.069 & 0.067 & $0.014^{* * * *}$ & -0.002 \\
\hline STDEBNSI $_{t}$ & 0.107 & 0.128 & 0.124 & $0.021^{* * *}$ & -0.004 \\
\hline $\mathrm{RET}_{t}$ & 0.131 & 0.191 & 0.103 & $0.061^{* * *}$ & $-0.089^{* * *}$ \\
\hline $\mathrm{D}_{\mathrm{NEG}, t}$ & 0.427 & 0.330 & 0.421 & $-0.097^{* * *}$ & $0.091^{* * *}$ \\
\hline STDRET $_{t}$ & 0.929 & 1.103 & 0.884 & $0.174^{* * *}$ & $-0.219^{* * *}$ \\
\hline LOGASSETS $_{t}$ & 7.080 & 7.220 & 7.415 & $0.140^{* * *}$ & $0.195^{* * *}$ \\
\hline $\mathrm{INVOPP}_{t}$ & 2.076 & 2.081 & 1.890 & 0.006 & $-0.191^{* * *}$ \\
\hline $\mathrm{NSI}_{t}$ & 0.021 & 0.017 & 0.023 & $-0.004^{* * *}$ & $0.006^{* * * *}$ \\
\hline $\mathrm{CS}_{t}$ (McVay) & 0.022 & 0.021 & 0.022 & -0.001 & 0.001 \\
\hline $\mathrm{CS}_{t}$ (Fan et al.) & 0.018 & 0.018 & 0.022 & 0.000 & $0.003^{* * *}$ \\
\hline $\mathrm{IND}_{\mathrm{BD}, t}$ & 1.285 & 2.204 & 2.632 & $0.918^{* * *}$ & $0.428^{* * *}$ \\
\hline $\mathrm{GOV}_{t}$ & -0.196 & 0.142 & 0.224 & $0.338^{* * *}$ & $0.082^{* * *}$ \\
\hline
\end{tabular}

Note: The pre-SOX period is 1998-2002 for board and committee independence. ***, **, * represents significance at $1 \%, 5 \%$, and $10 \%$ level, respectively.

Panel C: Summary statistics by the non-compliance status prior to the passage of SOX

\begin{tabular}{|c|c|c|c|}
\hline Variable & $\begin{array}{c}\text { (a) } \\
\text { Compliant firms } \\
(\mathrm{N}=1856)\end{array}$ & $\begin{array}{c}\text { (b) } \\
\text { Non-compliant firms } \\
(\mathrm{N}=446)\end{array}$ & $\begin{array}{c}\text { Mean } \\
\text { Differences } \\
(\mathrm{b}-\mathrm{a}) \\
\end{array}$ \\
\hline UE_CE $t$ (McVay) & 0.024 & 0.025 & 0.001 \\
\hline $\mathrm{UE}_{\mathrm{CE}} \mathrm{CE}_{t}$ (Fan et al.) & 0.019 & 0.021 & 0.002 \\
\hline $\mathrm{NSI}_{t}$ & 0.020 & 0.015 & $-0.005^{*}$ \\
\hline $\operatorname{INCPAY}_{t}(\log 1+$ mil. $)$ & 1.204 & 1.006 & $-0.199^{* * *}$ \\
\hline $\mathrm{EBNSI}_{t}$ & 0.076 & 0.066 & $-0.010^{* *}$ \\
\hline STDEBNSI $_{t}$ & 0.085 & 0.082 & -0.003 \\
\hline $\mathrm{RET}_{t}$ & 0.195 & 0.223 & 0.028 \\
\hline $\mathrm{D}_{\mathrm{NEG}, t}$ & -0.071 & -0.073 & -0.002 \\
\hline $\mathrm{STDRET}_{t}$ & 0.936 & 0.999 & 0.063 \\
\hline $\mathrm{INVOPP}_{t}$ & 2.069 & 2.074 & 0.005 \\
\hline LOGASSETS $_{t}$ & 7.572 & 7.304 & $-0.269^{* * *}$ \\
\hline $\mathrm{CS}_{t}$ (McVay) & 0.025 & 0.020 & $-0.005^{*}$ \\
\hline $\mathrm{NSI}_{\mathrm{NCS}, t}$ (McVay) & -0.005 & -0.004 & 0.001 \\
\hline $\mathrm{CS}_{t}$ (Fan et al.) & 0.021 & 0.019 & -0.002 \\
\hline $\mathrm{NSI}_{\mathrm{NCS}, t}$ (Fan et. al.) & -0.001 & -0.004 & -0.003 \\
\hline
\end{tabular}

Note: The period is 2000-2006 (all observations for 2002 is omitted). ***, **, * represents significance at $1 \%, 5 \%$, and $10 \%$ level, respectively. 


\section{TABLE 3}

Classification shifting and compensation shielding - Base case

Table 3 presents classification shifting and compensation shielding. Panel A presents the regression of unexpected core earnings (UE_CE) on negative special items (NSI). See Panel B presents the regression of CEO total incentive pay on NSI and its components in 1995-2012.

$\mathrm{INCPAY}_{t}$ is the log of one plus CEO total incentive pay. $\mathrm{NSI}_{t}$ is negative special items deflated by sales. $\mathrm{CS}_{t}$ is the classification-shifted component of NSI. NSI $\mathrm{NCS}, t_{\text {is }}$ the non-classification-shifted component of NSI. EBNSI $t_{t}$ is income before extraordinary items and NSIs deflated by sales for year $t$; $\operatorname{StdEBNSI}_{t}$ is the standard deviation of EBNSI for the past five years (years $t-5$ to $t-1$ ); $\mathrm{RET}_{t}$ is annual stock returns including a dividend payment; $\mathrm{STDRET}_{t}$ is the standard deviation of RET for the past five years (years $t-5$ to $t-1$ ); $\mathrm{D}_{\mathrm{NEG}, t} \times \mathrm{RET}_{t}$ is negative stock returns; $\mathrm{INVOPP}_{t}$ is investment opportunities; and LOGASSETS ${ }_{t}$ is the logarithm of total assets at the start of year $t$. Year- and firm-fixed effects are controlled, and the coefficient on an intercept is not reported for brevity. ***,**,* indicate significance of each coefficient at the level of $1 \%, 5 \%, 10 \%$, respectively.

Panel A. Regression of unexpected core earnings on negative special items

\begin{tabular}{lcc}
\hline & \multicolumn{2}{c}{ Dependent variable $=$ UE_CE } \\
\cline { 2 - 3 } & (a) McVay & (b) Fan et al. \\
\hline NSI $_{t}$ & $0.258^{* * * *}$ & $-0.077^{* * * *}$ \\
& $(12.88)$ & $(-3.52)$ \\
Fixed effects (Year, Firm) & Yes & Yes \\
$\mathrm{N}$ & 16,795 & 16,795 \\
R-squared & 0.220 & 0.196 \\
\hline
\end{tabular}


TABLE 3 (Continued)

Panel B: Results of regressing CEO total incentive on the components of negative special items

\begin{tabular}{|c|c|c|c|}
\hline & \multicolumn{3}{|c|}{ Dependent variable $=$ INCPAY } \\
\hline & (a) & $\begin{array}{c}\text { (b) } \\
\text { CS from } \\
\text { McVay }\end{array}$ & $\begin{array}{c}\text { (c) } \\
\text { CS from Fan } \\
\text { et al. }\end{array}$ \\
\hline $\mathrm{NSI}_{t}$ & $\begin{array}{c}-0.311^{* * * *} \\
(-3.86)\end{array}$ & & \\
\hline $\mathrm{NSI}_{\mathrm{NCS}, t}$ & & $\begin{array}{l}-0.208^{* *} \\
(-2.39)\end{array}$ & $\begin{array}{c}-0.273^{* * *} \\
(-3.29)\end{array}$ \\
\hline $\mathrm{CS}_{t}$ & & $\begin{array}{c}-0.452^{* * *} \\
(-4.62)\end{array}$ & $\begin{array}{c}-0.415^{* * *} \\
(-3.76)\end{array}$ \\
\hline Control variables & & & \\
\hline EBNSI $_{t}$ & $\begin{array}{c}0.626^{* * *} \\
(13.26)\end{array}$ & $\begin{array}{l}0.631^{* * *} \\
(13.37)\end{array}$ & $\begin{array}{c}0.633^{* * *} \\
(13.38)\end{array}$ \\
\hline STDEBNSI $_{t}$ & $\begin{array}{c}-0.092^{* * *} \\
(-3.27)\end{array}$ & $\begin{array}{c}-0.093^{* * *} \\
(-3.30)\end{array}$ & $\begin{array}{c}-0.091^{* * *} \\
(-3.24)\end{array}$ \\
\hline $\mathrm{RET}_{t}$ & $\begin{array}{c}0.102^{* * *} \\
(8.52)\end{array}$ & $\begin{array}{c}0.102^{\text {**** }} \\
(8.46)\end{array}$ & $\begin{array}{c}0.102^{\text {*** }} \\
(8.45)\end{array}$ \\
\hline $\mathrm{D}_{\mathrm{NEG}, t} \times \mathrm{RET}_{t}$ & $\begin{array}{l}0.040 \\
(1.15)\end{array}$ & $\begin{array}{l}0.044 \\
(1.25)\end{array}$ & $\begin{array}{l}0.040 \\
(1.15)\end{array}$ \\
\hline $\mathrm{STDRET}_{t}$ & $\begin{array}{c}0.026^{* * *} \\
(3.74)\end{array}$ & $\begin{array}{c}0.027^{* * *} \\
(3.77)\end{array}$ & $\begin{array}{l}0.026^{* * *} \\
(3.75)\end{array}$ \\
\hline $\mathrm{INVOPP}_{\mathrm{t}}$ & $\begin{array}{c}0.035^{\text {*** }} \\
(5.16)\end{array}$ & $\begin{array}{c}0.035^{* * *} \\
(5.21)\end{array}$ & $\begin{array}{c}0.034^{* * * *} \\
(5.15)\end{array}$ \\
\hline LOGASSETS $_{t}$ & $\begin{array}{c}0.145^{* * *} \\
(12.63)\end{array}$ & $\begin{array}{c}0.146^{* * *} \\
(12.74)\end{array}$ & $\begin{array}{c}0.145^{* * *} \\
(12.66)\end{array}$ \\
\hline Fixed effects (Year, Firm) & Yes & Yes & Yes \\
\hline $\mathrm{N}$ & 16,795 & 16,795 & 16,795 \\
\hline R-squared & 0.676 & 0.676 & 0.676 \\
\hline $\begin{array}{l}\text { Tests for coefficient equali } \\
\mathrm{CS}_{t}-\mathrm{NSI}_{\mathrm{NCS}, t}\end{array}$ & & $\begin{array}{c}-0.244^{* * *} \\
(-2.67)\end{array}$ & $\begin{array}{l}-0.142 \\
(-1.58)\end{array}$ \\
\hline
\end{tabular}


TABLE 4

Effects of a regulatory change in board and committee independence on classification shifting and compensation shielding

Table 4 shows effects of a regulatory change in board and committee independence on classification shifting and compensation shielding. NCOMPLY $_{t}$ is an indicator for non-compliant firms for board or committees at the first shareholders' meeting occurring after the end of 1999 and the non-compliance status does not change prior to the passage of SOX (June 2002). NCOMPLY $t$ equals one if less than 100\% of committee members (50\% of board members) are independent and zero otherwise. POST $t$ is an indicator variable for the post-SOX period and equals one for the 2003-2006 period and zero for the 2000-2001. Since we control for firm-fixed effects, we do not report the coefficients on an intercept and NCOMPLY for brevity. ***.**, * indicate statistical significance at the 1\%, 5\%, and 10\% level, respectively.

Panel A. Effects of a regulatory change in board and committee independence on classification shifting (Testing H1)

\begin{tabular}{|c|c|c|c|c|c|c|c|}
\hline & \multirow{4}{*}{$\begin{array}{c}\text { Sign } \\
\text { (Hypothesis) }\end{array}$} & \multicolumn{6}{|c|}{ Dependent variable $=$ UE_CE } \\
\hline & & \multicolumn{6}{|c|}{ Regulatory change in the independence of } \\
\hline & & \multicolumn{2}{|c|}{ Comp. committee } & \multicolumn{2}{|c|}{ Audit committee } & \multicolumn{2}{|c|}{ Board of directors } \\
\hline & & (a) McVay & (b) Fan et al. & (c) McVay & (d) Fan et al. & (e) McVay & (f) Fan et al. \\
\hline $\mathrm{NSI}_{t}$ & $?$ & $\begin{array}{c}0.381^{* * * *} \\
(4.77)\end{array}$ & $\begin{array}{l}0.147 \\
(1.40)\end{array}$ & $\begin{array}{c}0.419^{* * *} \\
(3.88)\end{array}$ & $\begin{array}{l}0.126 \\
(1.66)\end{array}$ & $\begin{array}{c}0.511^{* * *} \\
(5.35)\end{array}$ & $\begin{array}{l}0.173^{*} \\
(2.73)\end{array}$ \\
\hline $\mathrm{NSI}_{t} \times \mathrm{NCOMPLY}_{t}$ & $?$ & $\begin{array}{l}0.181 \\
(1.12)\end{array}$ & $\begin{array}{l}-0.123 \\
(-0.41)\end{array}$ & $\begin{array}{l}-0.268^{*} \\
(-2.55)\end{array}$ & $\begin{array}{l}-0.297 \\
(-0.76)\end{array}$ & $\begin{array}{l}-0.196 \\
(-0.63)\end{array}$ & $\begin{array}{l}-0.417^{*} \\
(-2.20)\end{array}$ \\
\hline $\mathrm{NSI}_{t} \times \mathrm{POST}_{t}$ & $\begin{array}{c}- \\
(\mathrm{H} 1)\end{array}$ & $\begin{array}{l}-0.046 \\
(-0.30)\end{array}$ & $\begin{array}{c}-0.340^{* * *} \\
(-4.54)\end{array}$ & $\begin{array}{l}-0.030 \\
(-0.20)\end{array}$ & $\begin{array}{l}-0.296^{*} \\
(-2.35)\end{array}$ & $\begin{array}{l}-0.193 \\
(-1.24)\end{array}$ & $\begin{array}{c}-0.264^{* * *} \\
(-4.42)\end{array}$ \\
\hline $\mathrm{NSI}_{t} \times \mathrm{NCOMPLY}_{t} \times \mathrm{POST}_{t}$ & $\begin{array}{c}- \\
(\mathrm{H} 1)\end{array}$ & $\begin{array}{l}-0.233 \\
(-0.90)\end{array}$ & $\begin{array}{l}0.078 \\
(0.23)\end{array}$ & $\begin{array}{l}0.116 \\
(0.32)\end{array}$ & $\begin{array}{l}0.311 \\
(0.47)\end{array}$ & $\begin{array}{l}0.049 \\
(0.23)\end{array}$ & $\begin{array}{l}0.095 \\
(0.51)\end{array}$ \\
\hline $\mathrm{POST}_{t}$ & $?$ & $\begin{array}{l}0.000 \\
(0.04)\end{array}$ & $\begin{array}{l}-0.005 \\
(-0.80)\end{array}$ & $\begin{array}{l}-0.002 \\
(-0.29)\end{array}$ & $\begin{array}{l}-0.006 \\
(-1.87)\end{array}$ & $\begin{array}{l}0.009 \\
(1.02)\end{array}$ & $\begin{array}{l}0.003 \\
(0.82)\end{array}$ \\
\hline $\mathrm{NCOMPLY}_{t} \times \mathrm{POST}_{t}$ & $?$ & $\begin{array}{l}-0.005 \\
(-0.43)\end{array}$ & $\begin{array}{l}0.001 \\
(0.07)\end{array}$ & $\begin{array}{l}-0.008 \\
(-1.66)\end{array}$ & $\begin{array}{l}-0.004 \\
(-0.64)\end{array}$ & $\begin{array}{l}-0.015 \\
(-1.14)\end{array}$ & $\begin{array}{l}-0.009 \\
(-0.85)\end{array}$ \\
\hline $\begin{array}{l}\text { Fixed effects (Firm) } \\
\text { Year-clustering effects }\end{array}$ & & $\begin{array}{l}\text { Yes } \\
\text { Yes }\end{array}$ & $\begin{array}{l}\text { Yes } \\
\text { Yes }\end{array}$ & $\begin{array}{l}\text { Yes } \\
\text { Yes }\end{array}$ & $\begin{array}{l}\text { Yes } \\
\text { Yes }\end{array}$ & $\begin{array}{l}\text { Yes } \\
\text { Yes }\end{array}$ & $\begin{array}{l}\text { Yes } \\
\text { Yes }\end{array}$ \\
\hline $\mathrm{N}$ & & 2,302 & 2,302 & 2,218 & 2,218 & 3,208 & 3,208 \\
\hline R-squared & & 0.405 & 0.308 & 0.485 & 0.363 & 0.381 & 0.298 \\
\hline
\end{tabular}


TABLE 4 (Continued)

Panel B. Effects of a regulatory change in board and committee independence on compensation shielding (Testing H2)

\begin{tabular}{|c|c|c|c|c|c|c|c|}
\hline & \multirow{4}{*}{$\begin{array}{c}\text { Sign } \\
\text { (Hypothesis) }\end{array}$} & \multicolumn{6}{|c|}{ Dependent variable $=$ INCPAY } \\
\hline & & \multicolumn{6}{|c|}{ Regulatory change in the independence of } \\
\hline & & \multicolumn{2}{|c|}{ Comp. committee } & \multicolumn{2}{|c|}{ Audit committee } & \multicolumn{2}{|c|}{ Board of directors } \\
\hline & & (a) McVay & (b) Fan et al. & (c) McVay & (d) Fan et al. & (e) McVay & (f) Fan et al. \\
\hline \multirow[t]{2}{*}{$\overline{\mathrm{NSI}_{\mathrm{NCS}, t}}$} & $?$ & 0.004 & -0.053 & 0.635 & 0.359 & 0.068 & 0.043 \\
\hline & & $(0.01)$ & $(-0.14)$ & $(1.54)$ & $(0.85)$ & $(0.13)$ & $(0.13)$ \\
\hline \multirow[t]{2}{*}{$\mathrm{CS}_{t}$} & $?$ & 0.677 & $1.062^{*}$ & $1.341^{* * *}$ & $1.533^{* *}$ & $0.863^{* *}$ & 1.165 \\
\hline & & $(1.78)$ & $(1.99)$ & $(4.94)$ & $(2.70)$ & $(2.62)$ & $(1.68)$ \\
\hline \multirow[t]{2}{*}{$\mathrm{NSI}_{\mathrm{NCS}, t} \times \mathrm{NCOMPLY}_{t}$} & $?$ & 0.962 & $1.666^{*}$ & -0.039 & 0.446 & 0.396 & 0.364 \\
\hline & & $(1.07)$ & $(2.10)$ & $(-0.06)$ & $(0.94)$ & $(0.62)$ & $(1.05)$ \\
\hline \multirow[t]{2}{*}{$\mathrm{CS}_{t} \times \mathrm{NCOMPLY}_{t}$} & $?$ & $2.347^{* *}$ & $1.662^{* *}$ & 0.009 & 0.044 & -0.239 & -0.329 \\
\hline & & (3.84) & $(2.60)$ & $(0.01)$ & $(0.06)$ & $(-0.33)$ & $(-0.31)$ \\
\hline \multirow[t]{2}{*}{$\mathrm{NSI}_{\mathrm{NCS}, t} \times \mathrm{POST}_{t}$} & $?$ & -0.085 & -0.469 & -0.628 & -0.847 & -0.541 & -1.814 \\
\hline & & $(-0.11)$ & $(-0.68)$ & $(-0.94)$ & $(-1.43)$ & $(-0.70)$ & $(-1.37)$ \\
\hline \multirow[t]{2}{*}{$\mathrm{CS}_{t} \times \mathrm{POST}_{t}$} & - & $-2.118^{*}$ & $-2.999^{* *}$ & $-2.536^{* * *}$ & $-3.080^{* * * *}$ & $-2.420^{* * *}$ & $-2.970^{* * * *}$ \\
\hline & $(\mathrm{H} 2)$ & $(-2.18)$ & $(-3.64)$ & $(-3.06)$ & $(-4.10)$ & $(-3.22)$ & $(-3.82)$ \\
\hline \multirow[t]{2}{*}{$\mathrm{NSI}_{\mathrm{NCS}, t} \times \mathrm{POST}_{t} \times \mathrm{NCOMPLY}_{t}$} & $?$ & $-2.718^{*}$ & $-2.942^{* *}$ & -1.457 & -1.281 & -0.181 & -0.251 \\
\hline & & $(-2.21)$ & $(-2.67)$ & $(-1.36)$ & $(-1.54)$ & $(-0.15)$ & $(-0.22)$ \\
\hline \multirow{2}{*}{$\mathrm{CS}_{t \times} \mathrm{POST}_{t \times} \mathrm{NCOMPLY}_{t}$} & - & $-2.741^{*}$ & $-1.742^{*}$ & -1.375 & $-1.327^{*}$ & 0.689 & 0.759 \\
\hline & $(\mathrm{H} 2)$ & $(-2.50)$ & $(-2.00)$ & $(-1.55)$ & $(-2.00)$ & $(0.55)$ & $(0.52)$ \\
\hline \multirow[t]{2}{*}{$\overline{\mathrm{POST}_{t}}$} & $?$ & $0.061^{* *}$ & $0.075^{* *}$ & $0.089^{* *}$ & $0.096^{* *}$ & $-0.083^{*}$ & $0.105^{* *}$ \\
\hline & & (2.89) & $(3.26)$ & $(3.01)$ & (3.34) & $(-2.19)$ & $(3.22)$ \\
\hline \multirow[t]{2}{*}{$\mathrm{POST}_{t} \times \mathrm{NCOMPLY}_{t}$} & $?$ & $0.131^{*}$ & $0.114^{*}$ & 0.050 & 0.049 & -0.018 & -0.022 \\
\hline & & $(2.30)$ & $(2.20)$ & (1.53) & (1.73) & $(-0.37)$ & $(-0.42)$ \\
\hline
\end{tabular}


TABLE 4 (Continued)

\begin{tabular}{|c|c|c|c|c|c|c|}
\hline & \multicolumn{6}{|c|}{ Regulatory change in the independence of } \\
\hline & \multicolumn{2}{|c|}{ Comp. committee } & \multicolumn{2}{|c|}{ Audit committee } & \multicolumn{2}{|c|}{ Board of directors } \\
\hline & (a) McVay & (b) Fan et al. & (c) McVay & (d) Fan et al. & (e) McVay & (f) Fan et al. \\
\hline \multicolumn{7}{|l|}{ Control variables } \\
\hline EBNSI $_{t}$ & $\begin{array}{c}1.263^{* * *} \\
(6.71)\end{array}$ & $\begin{array}{c}1.226^{* * *} \\
(6.67)\end{array}$ & $\begin{array}{l}1.578^{* * *} \\
(8.87)\end{array}$ & $\begin{array}{c}1.533^{* * *} \\
(7.84)\end{array}$ & $\begin{array}{c}1.057^{* * *} \\
(6.71)\end{array}$ & $\begin{array}{c}1.118^{* * *} \\
(7.09)\end{array}$ \\
\hline STDEBNSI $_{t}$ & $\begin{array}{c}-0.405^{* * *} \\
(-5.50)\end{array}$ & $\begin{array}{c}-0.443^{* * *} \\
(-6.91)\end{array}$ & $\begin{array}{c}-0.319^{* * *} \\
(-5.17)\end{array}$ & $\begin{array}{c}-0.343^{* * *} \\
(-6.38)\end{array}$ & $\begin{array}{c}-0.351^{* * *} \\
(-11.55)\end{array}$ & $\begin{array}{l}-0.343^{* *} \\
(-21.25)\end{array}$ \\
\hline $\mathrm{RET}_{t}$ & $\begin{array}{l}0.107^{*} \\
(2.38)\end{array}$ & $\begin{array}{l}0.110^{*} \\
(2.33)\end{array}$ & $\begin{array}{l}0.090 \\
(1.62)\end{array}$ & $\begin{array}{l}0.093 \\
(1.62)\end{array}$ & $\begin{array}{c}0.129^{* * *} \\
(4.20)\end{array}$ & $\begin{array}{l}0.102^{* * *} \\
(2.53)\end{array}$ \\
\hline $\mathrm{D}_{\mathrm{NEG}, \mathrm{t} \times} \times \mathrm{RET}_{t}$ & $\begin{array}{l}-0.113 \\
(-0.62)\end{array}$ & $\begin{array}{l}-0.125 \\
(-0.69)\end{array}$ & $\begin{array}{l}-0.130 \\
(-0.61)\end{array}$ & $\begin{array}{l}-0.137 \\
(-0.65)\end{array}$ & $\begin{array}{l}-0.173 \\
(-1.13)\end{array}$ & $\begin{array}{l}-0.125 \\
(-0.88)\end{array}$ \\
\hline STDRET $_{t}$ & $\begin{array}{l}0.021 \\
(0.90)\end{array}$ & $\begin{array}{l}0.021 \\
(0.86)\end{array}$ & $\begin{array}{l}0.015 \\
(0.73)\end{array}$ & $\begin{array}{l}0.012 \\
(0.55)\end{array}$ & $\begin{array}{l}0.045^{*} \\
(2.51)\end{array}$ & $\begin{array}{l}0.029 \\
(1.73)\end{array}$ \\
\hline $\mathrm{INVOPP}_{t}$ & $\begin{array}{l}0.030 \\
(0.95)\end{array}$ & $\begin{array}{l}0.033 \\
(1.07)\end{array}$ & $\begin{array}{l}0.010 \\
(0.21)\end{array}$ & $\begin{array}{l}0.014 \\
(0.29)\end{array}$ & $\begin{array}{l}0.038 \\
(1.22)\end{array}$ & $\begin{array}{l}0.027 \\
(0.77)\end{array}$ \\
\hline LOGASSETS $_{t}$ & $\begin{array}{c}0.056^{* *} \\
(2.82)\end{array}$ & $\begin{array}{l}0.046^{*} \\
(2.18)\end{array}$ & $\begin{array}{l}0.052^{*} \\
(2.36)\end{array}$ & $\begin{array}{l}0.047^{*} \\
(2.38)\end{array}$ & $\begin{array}{l}0.014 \\
(0.34)\end{array}$ & $\begin{array}{l}0.047 \\
(1.73)\end{array}$ \\
\hline Fixed effects (Firm) & Yes & Yes & Yes & Yes & Yes & Yes \\
\hline Year-clustering effects & Yes & Yes & Yes & Yes & Yes & Yes \\
\hline $\mathrm{N}$ & 2,302 & 2,302 & 2,218 & 2,218 & 3,208 & 3,208 \\
\hline R-squared & 0.708 & 0.709 & 0.709 & 0.709 & 0.706 & 0.704 \\
\hline
\end{tabular}


TABLE 5

Effects of overall governance on classification shifting and compensation shielding

This table shows effects of overall governance on classification shifting and compensation shielding. The strength of overall governance is proxied by a corporate governance index. The index is formed by a factor analysis using variables pertaining to management characteristics, and board and ownership structure. All other variables are as defined in Table 4. An intercept and the coefficients on control variables are not reported for brevity. ***.**, * indicate statistical significance at the $1 \%, 5 \%$, and $10 \%$ level, respectively.

Panel A. Association between a corporate governance index and classification shifting (H1)

\begin{tabular}{lccc}
\hline & Sign & \multicolumn{2}{c}{ Dependent variable = UE_CE } \\
\cline { 3 - 4 } & (Hypothesis) & (a) McVay & (b) Fan et al. \\
\hline NSI $_{t}$ & $?$ & $0.341^{* * * *}$ & 0.012 \\
& & $(15.69)$ & $(0.52)$ \\
$\mathrm{GOV}_{t}$ & $?$ & -0.001 & -0.000 \\
& & $(-0.60)$ & $(-0.02)$ \\
\hline $\mathrm{NSI}_{t} \times \mathrm{GOV}_{t}$ & - & $-0.088^{* * * *}$ & $-0.083^{* * *}$ \\
& $(\mathrm{H} 1)$ & $(-3.70)$ & $(-3.30)$ \\
\hline Fixed effects (Firm, Year) & & Yes & Yes \\
\hline $\mathrm{N}$ & & 13,375 & 13,375 \\
R-squared & & 0.270 & 0.238 \\
\hline
\end{tabular}

Panel B. Association between a corporate governance index and compensation shielding (H2)

\begin{tabular}{lccc}
\hline & Sign & \multicolumn{2}{c}{ Dependent variable = INCPAY } \\
\cline { 3 - 4 } & (Hypothesis) & (a) McVay & (b) Fan et al. \\
\hline NSI $_{\mathrm{NCS}, t}$ & $?$ & $-0.249^{* * *}$ & $-0.271^{* * * *}$ \\
& & $(-2.35)$ & $(-2.65)$ \\
$\mathrm{CS}_{t}$ & $?$ & $-0.281^{* *}$ & $-0.272^{* *}$ \\
& & $(-2.41)$ & $(-2.05)$ \\
$\mathrm{GOV}_{t}$ & $?$ & $0.074^{* * *}$ & $0.071^{* * *}$ \\
& & $(8.01)$ & $(7.71)$ \\
$\mathrm{NSI}_{\mathrm{NCS}, t} \times \mathrm{GOV}_{t}$ & $?$ & -0.103 & -0.163 \\
& & $(-0.90)$ & $(-1.49)$ \\
\hline $\mathrm{CS}_{t} \times \mathrm{GOV}_{t}$ & - & $-0.370^{* * * *}$ & $-0.262^{* *}$ \\
& $(\mathrm{H} 2)$ & $(-3.09)$ & $(-1.96)$ \\
\hline Control variables & & & \\
EBNSI & & $0.734^{* * *}$ & $0.735^{* * * *}$ \\
& & $(11.63)$ & $(11.61)$ \\
The other control variables & & Yes & Yes \\
Fixed effects (Firm, Year) & & Yes & Yes \\
\hline $\mathrm{N}$ & & 13,375 & 13,375 \\
R-squared & & 0.686 & 0.686 \\
\hline
\end{tabular}


TABLE 6

Effects changes in audit quality on classification shifting and compensation shielding

This table shows the effects of changes in audit quality on classification shifting and compensation shielding. $\mathrm{CH} \_\mathrm{AUB} 4_{t}$ is an indicator variable for an auditor change in year $t$ from a non-Big 4 firm or from a Big-4 firm to a Big 4 firm. $\mathrm{CH}_{-} \mathrm{AUNB}_{t}$ is an indicator variable for an auditor change in year $t$ from a Big 4 or from a non-Big-4 firm to a non-Big 4 firm. The coefficients on control variables are not reported for brevity. An intercept is not reported with firm-fixed effects controlled. ***.**, * indicates statistical significance at the $1 \%, 5 \%$, and $10 \%$ level, respectively. In all panels of Table 6, Columns (a) and (b) use 16,795 observations.

Panel A. Effects of changes in audit quality on classification shifting (H1)

\begin{tabular}{|c|c|c|c|}
\hline & \multirow{2}{*}{$\begin{array}{c}\text { Sign } \\
\text { (Hypothesis) }\end{array}$} & \multicolumn{2}{|c|}{ Dependent variable $=\mathrm{UE} \_\mathrm{CE}$} \\
\hline & & (a) McVay & (b) Fan et al. \\
\hline $\mathrm{NSI}_{\mathrm{t}}$ & $?$ & $\begin{array}{c}0.282^{* * *} \\
(13.64)\end{array}$ & $\begin{array}{c}-0.056^{* *} \\
(-2.46)\end{array}$ \\
\hline $\mathrm{NSI}_{\mathrm{t}} \times \mathrm{CH} \_\mathrm{AUNB} 4_{t}$ & $\begin{array}{c}+ \\
(\mathrm{H} 1)\end{array}$ & $\begin{array}{l}0.514^{*} \\
(1.84)\end{array}$ & $\begin{array}{c}0.814^{* * *} \\
(2.66)\end{array}$ \\
\hline $\mathrm{NSI}_{\mathrm{t}} \times \mathrm{CH}_{-} \mathrm{AUB} 4_{t}$ & $\begin{array}{c}- \\
(\mathrm{H} 1) \\
\end{array}$ & $\begin{array}{c}-0.374^{* * *} \\
(-4.99) \\
\end{array}$ & $\begin{array}{c}-0.354^{* * *} \\
(-4.33) \\
\end{array}$ \\
\hline $\mathrm{CH}_{-} \mathrm{AUNB} 4_{t}$ & $?$ & $\begin{array}{l}0.005 \\
(0.36)\end{array}$ & $\begin{array}{l}0.004 \\
(0.26)\end{array}$ \\
\hline CH_AUB4 ${ }_{t}$ & ? & $\begin{array}{l}-0.010^{*} \\
(-1.72)\end{array}$ & $\begin{array}{l}-0.010 \\
(-1.49)\end{array}$ \\
\hline Fixed effects (Firm, Year) & & Yes & Yes \\
\hline $\mathrm{N}$ & & 16,795 & 16,795 \\
\hline R-squared & & 0.222 & 0.198 \\
\hline
\end{tabular}


TABLE 6 (Continued)

Panel B. Effects of changes in audit quality on compensation shielding (H2)

\begin{tabular}{|c|c|c|c|}
\hline & \multirow{2}{*}{$\begin{array}{c}\text { Sign } \\
\text { (Hypothesis) }\end{array}$} & \multicolumn{2}{|c|}{ Dependent variable $=$ INCPAY } \\
\hline & & (a) McVay & (b) Fan et al. \\
\hline $\mathrm{NSI}_{\mathrm{NCS}, t}$ & $?$ & $\begin{array}{c}-0.183^{* *} \\
(-2.05)\end{array}$ & $\begin{array}{c}-0.255^{* * *} \\
(-2.99)\end{array}$ \\
\hline $\mathrm{CS}_{t}$ & $?$ & $\begin{array}{c}-0.413^{* * *} \\
(-4.13)\end{array}$ & $\begin{array}{c}-0.380^{* * *} \\
(-3.34)\end{array}$ \\
\hline $\mathrm{NSI}_{\mathrm{NCS}, t} \times \mathrm{CH} \_\mathrm{AUNB} 4_{t}$ & $?$ & $\begin{array}{l}0.643 \\
(0.60) \\
\end{array}$ & $\begin{array}{l}0.544 \\
(0.51) \\
\end{array}$ \\
\hline $\mathrm{CS}_{t} \times \mathrm{CH} \_\mathrm{AUNB} 4_{t}$ & $\begin{array}{c}+ \\
(\mathrm{H} 2) \\
\end{array}$ & $\begin{array}{l}0.392 \\
(0.39) \\
\end{array}$ & $\begin{array}{l}0.711 \\
(0.63) \\
\end{array}$ \\
\hline $\mathrm{NSI}_{\mathrm{NCS}, t} \times \mathrm{CH} \_\mathrm{AUB} 44_{t}$ & $?$ & $\begin{array}{l}-0.483 \\
(-1.42)\end{array}$ & $\begin{array}{l}-0.325 \\
(-1.03) \\
\end{array}$ \\
\hline $\mathrm{CS}_{t} \times \mathrm{CH} \_\mathrm{AUB} 4_{t}$ & $(\overline{\mathrm{H}})$ & $\begin{array}{c}-0.890^{* *} \\
(-2.11) \\
\end{array}$ & $\begin{array}{l}-0.721^{*} \\
(-1.65) \\
\end{array}$ \\
\hline$\overline{\mathrm{CH}} \_\mathrm{AUNB} 4_{t}$ & $?$ & $\begin{array}{l}-0.037 \\
(-0.70)\end{array}$ & $\begin{array}{l}-0.045 \\
(-0.84)\end{array}$ \\
\hline $\mathrm{CH} \_\mathrm{AUB} 4_{t}$ & $?$ & $\begin{array}{l}0.008 \\
(0.35)\end{array}$ & $\begin{array}{l}0.005 \\
(0.21)\end{array}$ \\
\hline $\begin{array}{l}\text { Control variables } \\
\text { EBNSI }_{t}\end{array}$ & & $\begin{array}{l}0.631^{* * *} \\
(13.35)\end{array}$ & $\begin{array}{l}0.631^{* * * *} \\
(13.33)\end{array}$ \\
\hline $\begin{array}{l}\text { The other control variables } \\
\text { Fixed effects (Firm, Year) }\end{array}$ & & $\begin{array}{l}\text { Yes } \\
\text { Yes } \\
\end{array}$ & $\begin{array}{l}\text { Yes } \\
\text { Yes }\end{array}$ \\
\hline $\begin{array}{l}\mathrm{N} \\
\mathrm{R} \text {-squared }\end{array}$ & & $\begin{array}{c}16,795 \\
0.676\end{array}$ & $\begin{array}{c}16,795 \\
0.676\end{array}$ \\
\hline
\end{tabular}


TABLE 7

Effects of overlapping membership on classification shifting and compensation shielding

This table shows effects of overlapping membership on compensation shielding. AUDCOMP is $_{t}$ an indicator variable for overlapping membership on the compensation and audit committees and equals one if the percentage of compensation committee members who are audit committee members exceed the sample median and zero otherwise. IND $\mathrm{AUD}, t$ is an indicator variable for an independent audit committee. An intercept and the coefficients on control variables are not reported for brevity. $* * * . * *, *$ indicate significance at the $1 \%, 5 \%$, and $10 \%$ level, respectively.

Panel A. Effect overlapping membership on classification shifting (Testing H1)

\begin{tabular}{|c|c|c|c|}
\hline & \multirow[t]{2}{*}{ Sign } & \multicolumn{2}{|c|}{ Dependent variable $=$ UE_CE } \\
\hline & & (a) McVay & (b) Fan et al. \\
\hline $\mathrm{NSI}_{t}$ & $?$ & $\begin{array}{l}0.075 \\
(1.08)\end{array}$ & $\begin{array}{c}-0.131^{*} \\
(-1.78)\end{array}$ \\
\hline $\mathrm{NSI}_{t} \times \mathrm{AUDCOMP}_{t}$ & $+/-$ & $\begin{array}{l}0.272^{* * *} \\
(3.15)\end{array}$ & $\begin{array}{l}0.085 \\
(0.93)\end{array}$ \\
\hline $\mathrm{NSI}_{t} \times \mathrm{IND}_{\mathrm{AUD}, t}$ & $\begin{array}{c}- \\
(\mathrm{H} 1)\end{array}$ & $\begin{array}{l}0.231^{* * *} \\
(2.94)\end{array}$ & $\begin{array}{l}0.088 \\
(1.06)\end{array}$ \\
\hline $\mathrm{NSI}_{t} \times \mathrm{IND}_{\mathrm{AUD}, t} \times \mathrm{AUDCOMP}_{t}$ & $+1-$ & $\begin{array}{l}-0.221^{* *} \\
(-2.24)\end{array}$ & $\begin{array}{l}-0.026 \\
(-0.24)\end{array}$ \\
\hline AUDCOMP $_{t}$ & $?$ & $\begin{array}{l}0.005 \\
(0.82)\end{array}$ & $\begin{array}{c}0.000 \\
(-0.08)\end{array}$ \\
\hline $\mathrm{IND}_{\mathrm{AUD}, t}$ & $?$ & $\begin{array}{l}0.006 \\
(1.14)\end{array}$ & $\begin{array}{l}0.003 \\
(0.48)\end{array}$ \\
\hline $\mathrm{IND}_{\mathrm{AUD}, t} \times \mathrm{AUDCOMP}_{\mathrm{t}}$ & $?$ & $\begin{array}{l}-0.006 \\
(-1.01)\end{array}$ & $\begin{array}{c}-0.001 \\
(-0.1)\end{array}$ \\
\hline Fixed effects (Firm, Year) & & Yes & Yes \\
\hline $\begin{array}{l}\mathrm{N} \\
\text { R-square }\end{array}$ & & $\begin{array}{c}11,734 \\
0.275\end{array}$ & $\begin{array}{c}11,734 \\
0.248\end{array}$ \\
\hline
\end{tabular}


Table 7 (Continued)

Panel B. Effect of overlapping membership on compensation shielding (Testing H2)

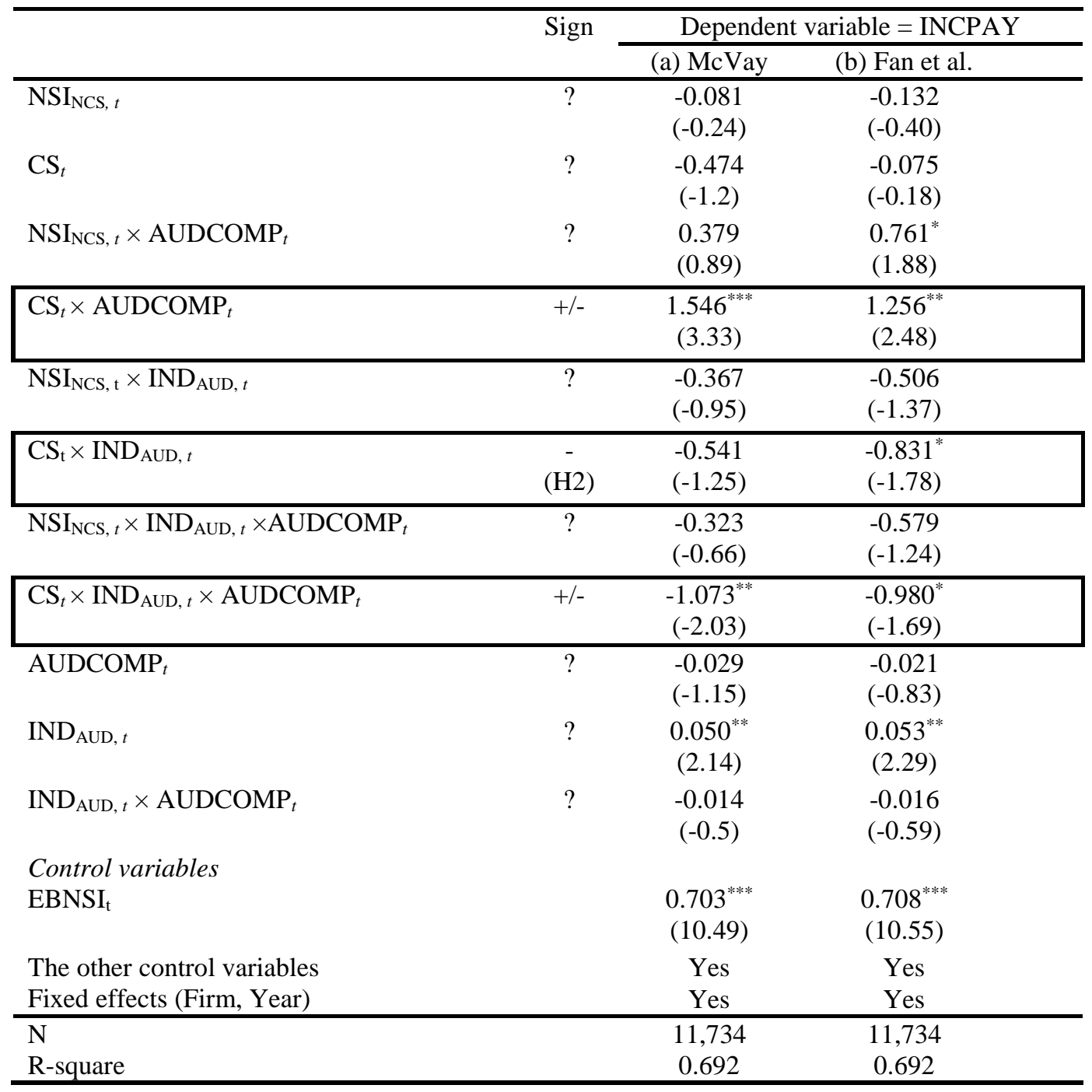

